\title{
WHAT LIES BENEATH: DETERMINING THE NECESSITY OF INTERNATIONAL GROUNDWATER POLICY ALONG THE UNITED STATES-MEXICO BORDER AND A ROADMAP TO AN AGREEMENT
}

I. INTRODUCTION . . . . . . . . . . . . . . . . . . 1212

II. SURVEYING THE LAND: UNDERSTANDING EXISTING CONDITIONS 1216

A. Understanding Groundwater ................. 1217

B. Historic Treatment of Water by International Law . . . . . . 1221

1. Sources of Law .......... . . . . . . . . . . . . 1221

a. History and Custom . . . . . . . . . . . . 1221

b. Interstate Law ..................... 1224

c. Nongovernmental and Intergovernmental Agencies ...................... 1226

2. Examples of Existing Groundwater Agreements and Treaties ........................... 1231

a. Franco-Swiss Genevese Aquifer Agreement ... 1231

b. Bellagio Draft Treaty .................. 1232

III. EXAmining the Water Situation Along the U.S.-MeXico

BORDER ............................ 1233

A. El Paso and Ciudad Juarez: A Case Study ............ 1234

B. International Boundary and Water Commission ........ 1236

C. Existing Water Agreements Along the U.S.-Mexico Border 1237

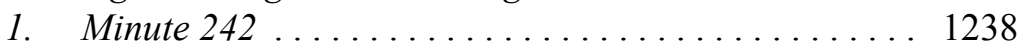

2. La Paz Agreement . . . . . . . . . . . . . . . . . 1238

3. North American Free Trade Agreement Side Accord . 1239

D. Looking Above the Surface: Water Law Along the Border . 1240

1. State Groundwater Law . . . . . . . . . . . . . . . . . 1240

a. Texas ......................... 1240

b. New Mexico ........................ 1241

c. Arizona ....................... 1242

d. California ...................... 1243

2. Mexican Groundwater Law . . . . . . . . . . . . . . 1243

IV. ANALYZING POLICY OPTIONS AND CREATING A ROADMAP TO AN AGREEMENT . . . . . . . . . . . . . . . . . . . . . . . . . . 1244

A. International Shared Oil \& Gas Law . . . . . . . . . . . . . 1245

B. International Environmental Law . . . . . . . . . . . . . . 1246

C. State Law ... . . . . . . . . . . . . . . . . . . . . . . . . . . . 1248

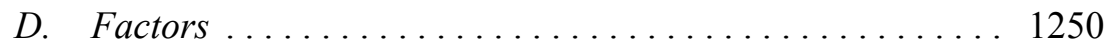

1. Approaching the Agreement . . . . . . . . . . . . 1250

2. Equitable Utilization .................. 1252

3. Surface Water/Groundwater Relationship ........ 1253 
4. Regional Agreements .................. 1254

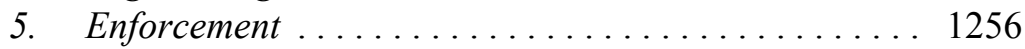

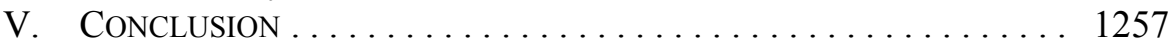

\section{INTRODUCTION}

In the western corner of Texas, the growing city of El Paso and its Mexican counterpart, Ciudad Juarez, are learning about the disappearance of a vital resource the hard way. ${ }^{1}$ These two cities share an ever increasing dependence on the Hueco Bolson Aquifer for all their water needs. ${ }^{2}$ Rapid population growth coupled with an annual rainfall of less than nine inches create the potential for severe water issues. ${ }^{3}$ Although both cities realize an impending crisis regarding their future water needs, no legal agreement or policy has been made to address the situation. ${ }^{4}$ It seems appropriate that in the year following the United Nations' (UN) "International Year of Freshwater," countries sharing groundwater resources should come together and create agreements to protect these precious and necessary resources. ${ }^{5}$

International water resources include "lakes, rivers[,] . . . aquifers, and any combination of these to which more than one state contributes or has access." Water does not recognize international boundaries and flows freely across borders from one country to another. ${ }^{7}$ Globalization of water and environmental issues has forced states to realize that because political boundaries are not recognized by water, the problems must be viewed in a broad, inclusive way. ${ }^{8}$ Narrow evaluation of the problem leads to increased competition and no protection of the shared resource. ${ }^{9}$

1. See Octavio E. Chavez, Mining of Internationally Shared Aquifers: The El Paso-Juarez Case, 40 NAT. RESOURCES J. 237, 237-39 (2000).

2. Id. at 237-38.

3. Id.; Records for El Paso, Extremes for El Paso, Texas 1879-1994, at http://rgfn.epcc.edu/users/ nwselp/recelp.html (last visited Oct. 5, 2003).

4. Chavez, supra note 1, at 237.

5. United Nations, International Year of Freshwater 2003, at http://www.wateryear2003.org (last visited Sept. 6, 2003). For the purposes of this comment, the word sharing will signify "transboundary," recognizing that the legal meaning of "sharing" can vary.

6. Eyal Benvenisti, Collective Action in the Utilization of Shared Freshwater: The Challenges of International Water Resources Law, 90 AM. J. INT'L L. 384, 398 (1996). The International Law Commission (ILC) does not currently include "unrelated confined groundwater," which is an aquifer that underlies an international boundary but is not hydrologically connected to surface water, as an international water source because of its isolated characteristics. Id. at 398,399 n.76. However, because shared resource problems still exist when both states have use access, unrelated confined aquifers will be included in the discussion with other types of aquifers for the purposes of this comment. See id. at 398.

7. Adrienne Paule, Underground Water: A Fugitive at the Border, 13 PACE ENVTL. L. REV. 1129, 1130 (1996).

8. Stephen McCaffrey, International Organizations and the Holistic Approach to Water Problems, 31 NAT. ResouRCES J. 139, 139-40 (1991).

9. Id. at 139 . 
Historically, many international agreements regarding resource allocation were motivated by one state seeking to gain an advantage over another country through control of a resource. ${ }^{10}$ Water is inherently different from other resources because of its life giving and sustaining potential; therefore, any agreement created to address a shared groundwater resource must be created in a cooperative manner. ${ }^{11}$ Water is not a legal issue; it is a life issue with legal ramifications. ${ }^{12}$ Because of the different needs for water versus other natural resources, different conflicts will arise for its attainment; therefore, states must shift from passive to active policy decision-making. ${ }^{13}$ Once this shift in thinking occurs, water policy can be created using a community-based approach to protect the survival of affected communities. ${ }^{14}$

The problems that can arise from an international shared resource are clearly seen on the United States-Mexico border. ${ }^{15}$ In addition to the Hueco Bolson Aquifer in El Paso, the two countries share several aquifers, and many are encountering problems with availability and contamination. ${ }^{16}$ The International Boundary and Water Commission (IBWC), an agency responsible for enforcing water treaties on the Mexico-United States border, recognized the need to develop a comprehensive groundwater agreement between the two countries, but little has been accomplished. ${ }^{17}$ Although significant attention has been given to international surface water, little to no policy has been generated regarding shared groundwater. ${ }^{18}$

Groundwater is generally defined as subsurface water existing below the water table. ${ }^{19}$ Although surface water and groundwater are distinct in many

10. Benvenisti, supra note 6 , at 393 .

11. See Chavez, supra note 1, at 237-39.

12. See Benvenisti, supra note 6, at 384 .

13. See G. Emlen Hall, Historical and Physical International Boundaries in Borderlands Water Conflicts: A Commentary, 40 NAT. ResourCES J. 865, 865 (2000).

14. See Benvenisti, supra note 6, at 392-93.

15. See Kate A. Berry, Water Along the Border: An Introduction to "Water Issues in the U.S.Mexico Borderlands," 40 NAT. RESOURCES J. 755 (2000).

16. See M. Diane Barber, The Legal Dilemma of Groundwater Under the Integrated Environmental Plan for the Mexican-United States Border Area, 24 St. MARY's L.J. 639, 646-48 (1993); Carlos Marin, Bi-National Border Water Supply Issues From the Perspective of the IBWC, 11 U.S.-MEX. L.J. 35, 35 (2003).

17. See Stephen P. Mumme, Minute 242 and Beyond: Challenges and Opportunities for Managing Transboundary Groundwater on the Mexico-U.S. Border, 40 NAT. RESOURCES J. 341, 341-42 (2000).

18. Dante A. Caponera \& Dominique Alheritiere, Principles for International Groundwater Law, 18 NAT. Resources J. 589, 591 (1978). Compare InT'L BOUNDARY \& WATER COMM'N, Minute 308, United States Allocation of Rio Grande Waters During the Last Year of the CuRRENT CyCle (2002) (showing an example of a surface water agreement between the United States and Mexico), available at http://www.Ibwc.state.gov/Files/Minutes/Minute 308.pdf, and INT'L BOUNDARY \& WATER COMM'N, Minute No. 307, Partial Coverage of Allocation of the Rio Grande Treaty Tributary Water DEFICIT FROM FORT QUITMAN TO FALCON DAM (2001) (showing an example of a surface water agreement between the United States and Mexico), available at $\mathrm{http}: / / \mathrm{www} . I b w c . s t a t e . g o v / f i l e s / m i n u t e s / \mathrm{min} 307 . p d f$, with Paule, supra note 7, at 1136 (explaining the lack of comparable groundwater agreements).

19. R. AlLAN FREEZE \& JOHN A. CHERRY, GROUNDWATER 2 (1979); see also infra notes 64-65 and accompanying text (providing a definition for groundwater). 
ways, they are often interrelated within the hydrologic cycle. ${ }^{20}$ The hydrologic cycle is the continuous circulation of water on earth. ${ }^{21}$ Water falls to the earth's surface as precipitation, such as rain or snow, creating surface water which seeps into the ground to become groundwater. ${ }^{22}$ In most cases, groundwater discharges in the form of surface water only to be evaporated into the atmosphere to start the cycle again. ${ }^{23}$ Pumping of groundwater from wells is the greatest artificial discharge which removes water, at least temporarily, from the hydrologic cycle. ${ }^{24}$

Two aspects of shared groundwater require examination. ${ }^{25}$ The first issue is use and allocation. ${ }^{26}$ Groundwater is a resource of growing importance because surface water resources are quickly being depleted. ${ }^{27}$ Several difficulties exist in raising public awareness of potential problems when no limitations are placed on groundwater usage. ${ }^{28}$ First, because aquifers are subterranean and not visible, it is often difficult to quantify water storage amounts. ${ }^{29}$ Storage capacity of an aquifer is estimated through a series of complex mathematical equations. ${ }^{30}$ Differing scientific methodologies mean that one set of results often contradicts another study's results and creates confusion for the public. ${ }^{31}$ An additional problem is that human nature dictates that something out of sight is out of mind; therefore, it often requires a crisis to realize the need for monitoring groundwater use. ${ }^{32}$

The second issue is protecting groundwater from contamination and pollution. ${ }^{33}$ Because society is becoming more and more dependant on groundwater as a drinking water source, pollution of an aquifer has

20. Thomas C. Winter et aL., U.S. Dep'T of the Interior, Ground Water and Surface WATER: A SiNGLE ResourCE 1-2, (U.S. Geological Survey Circular 1139, 1998).

21. See David Keith Todd, Groundwater Hydrology 13, 15-16 (2d ed. 1980).

22. Id.

23. $I d$.

24. Id. at 16 .

25. See infra notes $26-38$ and accompanying text.

26. Julio Barberis, The Development of International Law of Transboundary Groundwater, 31 NAT. RESOURCES J. 167, 169 (1991).

27. Payal Sampat, Deep Trouble: The Hidden Threat of Groundwater Pollution, 154 WORLDWATCH PAPER 1, 10-12 (2000).

28. See, e.g., FreEZE \& CHERry, supra note 19, at 58-62; Albert E. Utton, The Development of International Groundwater Law, 22 NAT. RESOURCES J. 95, 98 (1982).

29. See FREEZE \& CHERRY, supra note 19, at 58-62.

30. See id.

31. See, e.g., Jerry Needham, The Water Crisis: Aquifer's Tap Could Turn Tighter-More Pumping Restrictions May Spell Even Less Water for Parched Area, SAN ANTONIO EXPRESS-NEws, Aug. 11, 1996, available at 1996 WL 11493276. The U.S. Geologic Survey studies estimate the Edwards Aquifer in Texas has the capacity of forty-five million acre-feet, while other estimates are up to four times that figure. Id.

32. Ann Berkley Rodgers \& Albert E. Utton, The Ixtapa Draft Agreement Relating to the Use of Transboundary Groundwaters, in TRANSBOUNDARY RESOURCES LAW 151, 152-53 (Albert E. Utton \& Ludwik A. Teclaff eds., 1987); Ludwick A. Teclaff \& Eileen Teclaff, Transboundary Ground Water Pollution: Survey and Trends in Treaty Law, 19 NAT. ResourCES J. 629, 636 (1979).

33. See Barberis, supra note 26, at 169. 
increasingly dire consequences. ${ }^{34}$ This issue is further complicated in an international context. ${ }^{35}$ In cases of groundwater pollution extending past a nation's boundaries, liability issues develop. ${ }^{36}$ Turning to the United StatesMexico border, although the North American Free Trade Act (NAFTA) includes some environmental provisions, "not one treaty contains specific measures to prevent future groundwater pollution or provides measures for remediation of currently polluted aquifers." ${ }^{37}$ Because, by definition, any international agreement will involve at least two separate national governments, problems can also exist with enforcement of any policy regarding either use or pollution issues. ${ }^{38}$

What factors should be considered in the creation of new international groundwater policy if no laws currently exist? ${ }^{39}$ Can law from other disciplines be applied to groundwater? ${ }^{40}$ Although other sources of law can create the basis for policy, water's unique physical characteristics and uses require customized agreements. ${ }^{41}$ For example, some have suggested creating policy based on a model of other regulated international resources such as oil and gas. ${ }^{42}$ This notion is complicated by geologic variations. ${ }^{43}$ Many groundwater resources are renewable, distinguishing them from nonrenewable resources such as petroleum. ${ }^{44}$ Also, because water is necessary for more than economic benefits, it warrants different treatment in negotiations and agreements. ${ }^{45}$

The purpose of this comment is to demonstrate the immediate need for regional agreements to allocate shared groundwater along the United StatesMexico border. The comment will also evaluate policy options and list factors that should be considered in the creation of shared groundwater policy. ${ }^{46}$ Part II describes the basic geology of groundwater and how it has been historically treated by international law. ${ }^{47}$ Understanding the basics of groundwater systems and the interrelated nature of surface water and groundwater is critical in the formation of international agreements to predict how one action will

34. See id.

35. See id. 169-70.

36. Paule, supra note 7, at 1130.

37. Id. at 1132; see Aaron Holland, The North American Agreement on Environmental Cooperation: The Effect of the North American Free Trade Agreement on the Enforcement of the United States Environmental Law, 28 TEX. TECH L. REV. 1219 (1997).

38. Jesse H. Hamner \& Aaron T. Wolf, Patterns in International Water Resource Treaties: The Transboundary Freshwater Dispute Database, 1997 COLO. J. INT'L ENVTL. L. \& POL'Y 157, 166-67 (1997).

39. See discussion infra Part IV.

40. See discussion infra Part IV.C.

41. See discussion infra Part IV.A-C.

42. See Eyal Benvenisti, Sharing Transboundary Resources: International LaW AND Optimal Resource Use (2002).

43. See ToDD, supra note 21 , at 13,16 .

44. See id.

45. See United Nations, supra note 5.

46. See discussion infra Part IV.

47. See discussion infra Part II. 
affect other users. ${ }^{48}$ This section also discusses past water agreements, which can create a foundation for future agreements. ${ }^{49}$ It is also important to understand how groundwater has been historically viewed to assess what needs to be modified to affect change. ${ }^{50}$

Part III discusses the current groundwater situation along the United States-Mexico border. ${ }^{51}$ The section describes shared water resources and potential conflicts. ${ }^{52}$ It also reviews existing water law on both sides of the border. ${ }^{53}$ Any future agreement will have to be created according to the regional geology and coincide with existing regulations and regulatory agencies. ${ }^{54}$ Finally, Part IV provides a detailed look at policy options for future international groundwater law including the factors that should be considered in its creation. ${ }^{55}$ This section reviews aspects of past agreements and policies that have been successful and should be included in any future groundwater agreements. $^{56}$

\section{SURVEYING THE LAND: UNDERSTANDING EXISTING CONDITIONS}

Before new policy can be created, an understanding must be had regarding the local issues and historic precedent. ${ }^{57}$ The first important factor in any groundwater agreement is understanding regional geology and the basic characteristics of groundwater. ${ }^{58}$ Variations in the way two states can share groundwater can lead to different policy treatments. ${ }^{59}$

Policy makers should also review past agreements to understand historic treatment of groundwater. ${ }^{60}$ Although groundwater policy is a new, emerging field, any past agreements will create the foundation for future laws. ${ }^{61}$

48. See discussion infra Part II.

49. See discussion infra Part II.B.

50. See discussion infra Part II.

51. See discussion infra Part III.

52. See discussion infra Part III.

53. See discussion infra Part III.D.

54. See discussion infra Part III.

55. See discussion infra Part IV.

56. See discussion infra Part IV.

57. See infra text accompanying notes 63-271; Barberis, supra note 26, at 169-85; Gabriel Eckstein \& Yoram Eckstein, A Hydrogeological Approach to Transboundary Ground Water Resources and International Law, 19 AM. U. INT'L L. REV. 201, 222-31 (2003).

58. See discussion infra Part II.A; Eckstein \& Eckstein, supra note 57, at 207-22.

59. See Eckstein \& Eckstein, supra note 57, at 232-43.

60. See generally Caponera \& Alheritiere, supra note 18, at 589-600 (enumerating past groundwater agreements).

61. See, e.g., Bernard J. Wohlwend, An Overview of Groundwater in International Law, A Case Study: The Franco-Swiss Genevese Aquifer 1, 1 (2002), available at http://www.bjwconsult.com/The\%20 Genevese\%20Aquifer.pdf, (last visited Sept. 18, 2003). 
Knowledge of past laws and their origins will assist in cooperative efforts towards future agreements. ${ }^{62}$

\section{A. Understanding Groundwater}

Although many people assume all water sources are the same, surface water and groundwater are very distinct, though interrelated, resources. ${ }^{63}$ Groundwater is often incorrectly considered an underground river. ${ }^{64}$ It is better defined as:

[S]ubsurface water that occurs beneath the water table in soils and geologic formations that are fully saturated .... It is part of the hydrologic cycle, and an understanding of its role in this cycle is mandatory if integrated analyses are to be promoted in the consideration of watershed resources, and in the regional assessment of environmental contamination. ${ }^{65}$

The hydrologic cycle is an endless circulation of water between ocean, atmosphere, and land. ${ }^{66}$ Precipitation is dropped and carried as overland flow, commonly called surface water, and then infiltrated into the soil to become groundwater. ${ }^{67}$

Most groundwater is found in aquifers. ${ }^{68}$ An aquifer is defined as a "saturated permeable geologic unit that can transmit significant quantities of water under ordinary hydraulic gradients." ${ }^{69}$ The two major types of aquifers are confined and unconfined. ${ }^{70}$ A confined aquifer is restrained between two impermeable geologic layers physically separating it from the ground surface. ${ }^{71}$ Its isolation from the surface, however, does not necessarily mean a lack of interaction with surface water. ${ }^{72}$ In most cases, confined aquifers are recharged by recharge zones located at higher elevations at the surface, and the aquifer often discharges into rivers or lakes down gradient. ${ }^{73}$ A confined aquifer is often under pressure; as a result, the water level can rise above the

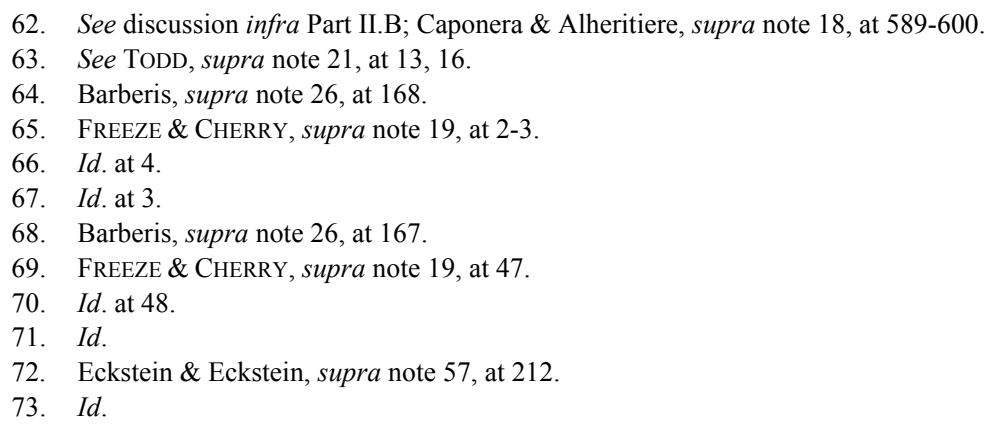


top of the aquifer. ${ }^{74}$ This water level is not the top of the aquifer; it is only a pressure surface created by the force of the overlying confining layer. ${ }^{75}$

The second type of aquifer is an unconfined aquifer. ${ }^{76}$ In this type of aquifer, the water table forms the upper boundary of the aquifer. ${ }^{77}$ This is an important distinction from a confined aquifer because an unconfined aquifer has no impediment between the top of the aquifer and the ground surface. ${ }^{78}$ Therefore, interaction between groundwater and surface water is more likely. ${ }^{79}$ It is also possible for an aquifer to be a combination of confined and unconfined. ${ }^{80}$

Unlike other natural resources, "the total volume of water in nature is fixed and invariable." ${ }^{81}$ This "world water balance" consists only of roughly $2.5 \%$ fresh water. ${ }^{82}$ A large portion of this is in solid form including icecaps and glaciers. ${ }^{83}$ Of the remaining amount of fresh water not in solid form, twothirds is groundwater. ${ }^{84}$

The danger of groundwater depletion is tied to residence times, or the amount of time water "lives" in a certain location. ${ }^{85}$ The turnover time of water in a river is approximately two weeks. ${ }^{86}$ In contrast, the turnover time for groundwater may be tens, hundreds, or possibly thousands of years. ${ }^{87}$ Therefore, although groundwater is technically a renewable resource, its renewability is severely limited by time and the world water balance. ${ }^{88} \mathrm{~A}$ technically renewable aquifer can recharge at such a rate that it is functionally nonrenewable. ${ }^{89}$

74. FREEZE \& CHERRY, supra note 19, at 48.

75. See id.

76. $I d$.

77. $I d$.

78. Id.

79. Id.

80. ToDD, supra note 21, at 42. The San Pedro Basin Aquifer is an example of a combination aquifer. See Hector M. Arias, International Groundwaters: The Upper San Pedro River Basin Case, 40 NAt. ResourCes J. 199, 204 (2000). This aquifer is shared by Mexico and the United States, and the unconfined groundwater flows in relation to the San Pedro River. Id. at 199-200, 204. In contrast, it becomes confined in the Palominas-Hereford and the St. David-Benson areas. Id. at 204. The groundwater issue in this area is not water availability, but rather water accessibility. See id. at 210. Excessive pumping in the area creates a cone, a depression large enough to disable surrounding pumps to reach the water table. Id.

81. Barberis, supra note 26, at 167.

82. Eckstein \& Eckstein, supra note 57, at 204 n.13.

83. Id.

84. Id.

85. See TODD, supra note 21 , at $24-25$

86. FREEZE \& CHERRY, supra note 19, at 5.

87. Id.

88. See id.

89. See, e.g., Rex Buchanan, Study Measures Recharge in the Ogallala Aquifer, KAN. GEOLOGICAL SERV. ๆף 7-8 (Dec. 19, 2003), at http://www.kgs.ukans.edu/General/News/2003/ogallala.html (last visited Feb. 1, 2004) (explaining that, although renewable, the Ogallala Aquifer recharges at a slower rate than it is being used, significantly lowering the water level). 
The United States relies on groundwater for half of its drinking-water needs. ${ }^{90}$ This percentage is much higher for rural users who depend on groundwater for almost $100 \%$ of their needs. ${ }^{91}$ Texas's average groundwater withdrawal in 1990 was almost eight billion gallons per day. ${ }^{92}$ By 1995 , Texas depended on groundwater for forty-five percent of its drinking water. ${ }^{93}$ This number increases yearly for many reasons, including population growth. ${ }^{94}$ In 1960, Texas's state population was less than ten million people. ${ }^{95}$ In the 2000 census, the population had grown to almost twenty-one million people and is currently growing at an estimated rate of 400,000 people per year. ${ }^{96}$

A natural resource is considered shared to the extent that the use of waters of an international watercourse system in the territory of one state can affect the use of waters of that system in the territory of another system state. ${ }^{97}$ An aquifer system includes both the recharge zone, natural discharge zones, and the actual aquifer because the quantity of water in an aquifer can be adversely affected by exploitation or by a modification of its sources of supply or discharge. ${ }^{98}$ It is necessary to define the type of shared resource in order to determine how it will be treated under international law. ${ }^{99}$ Two states can share a groundwater resource in several scenarios. ${ }^{100}$

The first category of shared groundwater is confined aquifers that cross an international boundary. ${ }^{101}$ Within confined aquifers two possibilities exist - those that have a hydrologic relationship to the surface water and those isolated bodies of water without any surface water interactions. ${ }^{102}$ In both models, international consequences occur if an aquifer lies completely within one state, but its recharge zone lies in another state. ${ }^{103}$

90. Eckstein \& Eckstein, supra note 57, at 201-02.

91. See Purdue University, American Population Water Supply, at http://pasture.ecn.purdue.edu/ agenhtml/agen521/epadir/grndwtr/population.html (last visited Mar. 25, 2004).

92. United States Geologic Survey, Water Science Map Gallery, at http://wwwga.usgs.gov/edu/ maptotalgw.html (last visited Mar. 17, 2004).

93. United States Geologic Survey, Ground Water Use in the United States, at http://wwwga.usgs. gov/edu/wugw.html (last visited Mar. 17, 2004).

94. See Utton, supra note 28, at 97.

95. Texas State Data Center \& Office of State Demographer, Total Resident Population and Percent Population Change in Texas: 1850 to 2000, at http://txsdc.tamu.edu (last visited Mar. 25, 2004).

96. U.S. Census Bureau, Annual Population Estimates by State, at http://quickfacts.census.gov/ qfd/states/48000.html (last modified Dec. 27, 2002).

97. See generally McCaffrey, supra note 8, at 154 .

98. See FREEZE \& CHERRY, supra note 19, at 4; Barberis, supra note 26, at 169.

99. Benvenisti, supra note 6, at 388 .

100. See Barberis, supra note 26, at 168-69.

101. See id. at 168; Eckstein \& Eckstein, supra note 57, at 244-48.

102. Eckstein \& Eckstein, supra note 57, at 234. Past assessments of shared aquifer possibilities did not make any distinctions and placed all confined aquifers in one general category. See Barberis, supra note 26 , at 168. This creates problems because of possible international law implications when the boundaries and characteristics of a shared aquifer are not well defined. Eckstein \& Eckstein, supra note 57, at 234.

103. Eckstein \& Eckstein, supra note 57, at 244-45. 
The second series of shared groundwater models are generated from an unconfined aquifer that is hydrologically linked with a river, and one or both water bodies traverse an international boundary. ${ }^{104}$ The first situation is an unconfined aquifer that traverses an international boundary linked hydrologically to a river that forms the boundary between two states. ${ }^{105} \mathrm{~A}$ slightly different scenario is one in which the aquifer traverses the international boundary, but the river crosses the international boundary instead of creating it. ${ }^{106}$ In this case, both the aquifer and the river cross the state boundary. ${ }^{107}$

The third model in this group is an aquifer that traverses the international boundary and a river that is located entirely within one state. ${ }^{108}$ This model is important because, although much of the recharge for the aquifer generated from the river is located in one state, the actual water source is shared by two states; the reverse is also possible. ${ }^{109}$ In the second series of models, it is important to determine if the river is effluent or influent. ${ }^{110}$ An effluent river is one in which the aquifer feeds the flow of the river, and an influent river is one that recharges the aquifer. ${ }^{111}$ The international implication of either situation is that one state can deplete one resource by mining the other one. ${ }^{112}$

The implications for each state will change dramatically depending on the model that exists. ${ }^{113}$ Understanding geology and how two states share a groundwater resource will affect the policy options. ${ }^{114}$ In addition to understanding the local geologic situation, law makers must also understand how groundwater has been historically treated. ${ }^{115}$ Past agreements and custom are strong indicators of future agreement terms. ${ }^{116}$

\section{B. Historic Treatment of Water by International Law}

104. Id. at 236-43.

105. Id. at 236-38.

106. Id. at 239-40. The San Pedro Basin Aquifer, which crosses the border between Mexico and Arizona, is an example of this aquifer model. Arias, supra note 80, at 199-200.

107. Eckstein \& Eckstein, supra note 57, at 239-40.

108. Id. at 241-42. The Mimbres Basin Aquifer, which crosses the border between Mexico and New Mexico, is an example of this scenario. Id. at 242.

109. See id.

110. Barberis, supra note 26, at 168.

111. See id. The Rio Grande River and the Hueco Bolson Aquifer along the United States-Mexico border is an example of this type of model. John Walton \& Gregory Ohlmacher, Surface and Ground Water Interactions: El Paso-Juarez Region, 1, 3 at http://rorykate.ce.utep.edu/surfgw/SCERP0997/SCERP MonographWWVersion.pdf. (last visited Mar. 25, 2004).

112. See Barberis, supra note 26, at 168.

113. See Eckstein \& Eckstein, supra note 57, at 235-48.

114. See id.

115. See Caponera \& Alheritiere, supra note 18, at 589.

116. See id. 
International law generally provides that states have the right to exploit their own resources but have the responsibility to not do so with other states' resources. ${ }^{117}$ Although the UN has stressed the need to apply this theory to shared water resources, it has never explicitly included groundwater. ${ }^{118}$ Historically, treaties and agreements that gave mention to international groundwater rarely made it the main focus; therefore, little consensus exists regarding how to approach these issues. ${ }^{119}$ Because of the lack of precedent, future international groundwater law must draw from a combination of sources, including past international law, existing agreements, and local treatment of groundwater. ${ }^{120}$ These sources provide the basis for future policy. ${ }^{121}$

\section{Sources of Law}

Law is generated from various sources. ${ }^{122}$ It is frequently created from past laws, expert opinions, or human experience. ${ }^{123}$ Sources found within the state can provide guidance. ${ }^{124}$ Communities create laws based on what they know. ${ }^{125}$ Understanding this subtle element is the first step to a workable policy for a community. ${ }^{126}$

\section{a. History and Custom}

International law often finds its origins in Roman Law. ${ }^{127}$ Under Roman Law, groundwater was either included in ownership or a commodity, which could be purchased. ${ }^{128}$ The Roman theory of resource ownership attaching to the land was adopted by French and Spanish Civil Code in the late 1800s. ${ }^{129}$ The law dictated that full use of springs located on the property was acceptable as long as it did not negatively affect a neighbor. ${ }^{130}$ English Common Law also held that groundwater was part of the overlying land. ${ }^{131}$ This theory was

117. G.A. Res. 2995, U.N. GAOR, 27th Sess., at 42 (1972), available at http://ods-dds.ny.un.org/doc (last visited Sept. 16, 2003).

118. Caponera \& Alheritiere, supra note 18, at 613 (citing Report of the United Nations Water Conference, Mar del Plata Conference, at 51, U.N. Doc. E/Conf.70/CBP/1 (1977)).

119. Eckstein \& Eckstein, supra note 57, at 222-31.

120. See Caponera \& Alheritiere, supra note 18, at 589.

121. See id.

122. See id.

123. See id.

124. See id.

125. See, e.g., Texas v. New Mexico, 462 U.S. 554 (1983) (looking to precedent to reach a decision).

126. See Hamner \& Wolf, supra note 38 , at 159.

127. Caponera \& Alheritiere, supra note 18 , at 598.

128. Id. at 599.

129. Id. at 598-99.

130. Id.

131. Eckstein \& Eckstein, supra note 57, at 222-23. 
adopted by the United States, ${ }^{132}$ but many states have since modified this practice. ${ }^{133}$

Custom has always played a role in how a culture deals with water, and laws often reflect current societal views. ${ }^{134}$ "Treaties can tell about regional hegemony, about how and which water needs are met, about the relative importance of water in the political climate, about development issues, and whether earlier treaties have successfully guided or guaranteed state behavior." 135 This can be seen in the previously omnipresent United States law and enduring Texas law of "right of capture." 136 Texas's pervasive culture of private ownership causes citizens to think property possession extends to unlimited use of all associated resources, which creates a significant barrier to groundwater law modification. ${ }^{137}$ Because law is often a reflection of culture, custom should be considered in the creation of water agreements. ${ }^{138}$

The custom regarding shared resource situations has often resulted in one state attempting to gain control of the groundwater source to obtain power over another state. ${ }^{139}$ Because water has unique implications, states must avoid trying to "increase the power gap" by controlling the resource and cooperate with the sharing state. ${ }^{140}$ A government must balance the needs of its domestic groups as well as the other state's interest. ${ }^{141}$

Multilateral water agreements generally fall into one of three categories. ${ }^{142}$ The "content of water" agreements include, among other things, navigation, water supply, and quality. ${ }^{143}$ In these agreements water is not the purpose of the agreement, but the vehicle to achieve another goal. ${ }^{144}$ The

132. Caponera \& Alheritiere, supra note 18 , at 599.

133. See Paule, supra note 7, at 1139-42.

134. See Ludwik A. Teclaff, Fiat or Custom: the Checkered Development of International Water Law, 31 NAt. Resources J. 45, 63 (1991); Leonard B. Dworsky \& Albert E. Utton, Assessing North America's Management of its Transboundary Waters, 33 NAT. RESOURCES J. 413, 440-41 (1993) (explaining that conflicts on the U.S.-Mexico border are often a reflection of "the way United States citizens have been trained to think about Mexico and Mexicans" and differences between Mexican and United States common law systems regarding land tenure).

135. Hamner \& Wolf, supra note 38, at 159.

136. Eric Opiela, The Rule of Capture in Texas: An Outdated Principle Beyond its Time, 6 U. DENV. WATER L. REV. 87, 88 (2002).

137. Ronald Kaiser \& Frank F. Skillern, Deep Trouble: Options for Managing the Hidden Threat of Aquifer Depletion in Texas, 32 TeX. Tech L. Rev. 249, 250-251 (2001). See also Sipriano v. Great Spring Waters of Am., Inc., 1 S.W.3d 75, 76-77 (Tex. 1998) (stating that not upholding the rule of capture would interfere with " 'drainage and agriculture, mining, the construction of highways and railroads, with sanitary regulations, building, and the general progress of improvement in works of embellishment and utility'” (quoting Houston \& Tex. Cent. Ry. v. East, 81 S.W. 279, 281 (Tex. 1904)).

138. See Teclaff, supra note 134 , at 63.

139. See Benvenisti, supra note 6, at 393.

140. See id.

141. Id.

142. James L. Wescoat, Jr., Main Currents in Early Mutilateral Water Treaties: A HistoricalGeographic Perspective, 1648-1948, 7 COLO. J. INT'L L. \& POL'Y 39, 43 (1996).

143. Id.

144. Id. 
"territorial context of water" agreements mainly focus on distribution of property after a dispute and mention water in boundary agreements. ${ }^{145}$ Finally, in "written context" agreements, water is the sole subject of the treaty, a major topic, or minor clause. ${ }^{146}$

The majority of historic water treaties focused on navigation of surface water. ${ }^{147}$ It has only been in recent years that water treaties were formed for the purpose of water allocation, although very few of these dealt with groundwater. ${ }^{148}$ Other historic treaties focused on other factors such as defense, national boundaries, and flood control. ${ }^{149}$

Recently, as the demand for water resources and the scarcity of water have increased, more water treaties have been created to define allocation. ${ }^{150}$ Four general trends have been recognized in water allocation treaties. ${ }^{151}$ The first is a shift from a rights-based to a need-based approach. ${ }^{152}$ Second, in disputes between upstream and downstream riparian users, needs of the downstream riparian are more often delineated. ${ }^{153}$ Third, economic benefits are not explicitly used in allocating water, and finally, the uniqueness of the basin becomes an explicit part of the treaty. ${ }^{154}$

Learning local custom and historic groundwater law creates a background for future policy, but it does not provide specific terms to include in an agreement. ${ }^{155}$ To gain ideas of legal options, one must turn to something more concrete. ${ }^{156}$ This is difficult because little existing policy has been created, but analogies can be made to similar struggles occurring within a nation's boundaries. ${ }^{157}$

\section{b. Interstate Law}

145. Id. at 46 .

146. Id. at 49 .

147. Hamner \& Wolf, supra note 38, at 158.

148. Id. at 162-64. Examples of past treaties that included groundwater include (1) the 1925 agreement between Egypt and Italy on the Ramba Well, (2) the 1927 Convention of Protocol between the USSR and Turkey regarding the use of frontier waters, (3) the 1947 Treaty of Peace between the Allies and Italy, and (4) the 1958 agreement concerning water economy between Yugoslavia and Bulgaria. Caponera \& Alheritiere, supra note 18, at 593.

149. Wescoat, supra note 142, at 51-52.

150. See Caponera \& Alheritiere, supra note 18, at 591-94.

151. Hamner \& Wolf, supra note 38 , at 162-63.

152. Id. at 162 .

153. Id. at $162-63$.

154. Id. at 163.

155. See id. at 159.

156. See Utton, supra note 28, at 104-05.

157. See, e.g., Nebraska v. Wyoming, 325 U.S. 589 (1945); Washington v. Oregon, 297 U.S. 517 (1936); Colorado v. New Mexico, 459 U.S. 176 (1982) (providing examples of interstate water conflicts within the United States). 
International water policy often finds its source in interstate law. ${ }^{158}$ Although technically not international law, the interstate laws of some influential countries, such as Canada and the United States, have provided the basis for international agreements. ${ }^{159}$ Some interstate conflicts can also create international conflicts. ${ }^{160}$ For example, a water allocation conflict between New Mexico and Texas may also impact Mexico. ${ }^{161}$

The three mechanisms which states use to create interstate cooperative agreements are "1) the interstate agreement or compact, which creates rules for regulating the relationship between the parties; 2) judicial decision, which ascertains the existing better rights as between the parties; and 3) paramount federal power." 162

National systems vary in the amount of power given to the government to control water use. ${ }^{163}$ Some systems give their government great latitude to solve water disputes while others favor a more decentralized approach. ${ }^{164}$ The United States has more interstate compacts than any other country, although few deal with groundwater. ${ }^{165}$ The goal of the majority of water allocation agreements is equal distribution of the resource. ${ }^{166}$ In some parts of the United States, associations, at a local level, have been formed to evaluate the exchange of information regarding water needs and management issues of the neighboring states. ${ }^{167}$

In situations where interstate cooperation failed, the courts have stepped in to solve shared resource problems. ${ }^{168}$ Decisions of interstate conflicts have focused on fair division of the water and good faith use to ensure that one person's use does not harm another's use. ${ }^{169}$ In the early case of Nebraska $v$. Wyoming, Nebraska brought suit against Wyoming alleging that Wyoming and

158. Utton, supra note 28 , at 104.

159. Id. at 104-05.

160. See Chavez, supra note 1, at 241.

161. See id.

162. Caponera \& Alheritiere, supra note 18 , at 604

163. See id. at 604-06.

164. See id. at 604-05. The Swiss government is an example of a broad allocation of power allowing for government intervention and control where necessary. $I d$. at 604 . This is in contrast to Germany and Canada which favor a more decentralized approach, leaving water agreements in the hands of the localities affected. Id. at 604-05.

165. Id. at 606. An example of interstate groundwater agreements include the Delaware River Basin Compact, which must balance the needs of New York, New Jersey, Pennsylvania, and Delaware. Id. at 60607. The compact controls both groundwater and surface water withdrawals in addition to monitoring pollution control. $I d$. at 607 . Other interstate agreements with groundwater references include the Lower Niobrara River and Ponca Creek Compact between Nebraska and South Dakota and the Upper Niobrara River Basin Compact between Nebraska and Wyoming. Id. at 606-07.

166. Id. at 606 .

167. Id. at 608. In 1975, Texas, Oklahoma, Colorado, Kansas, and Nebraska formed a Groundwater Management Districts Association to create a vehicle for the exchange of information. Id.

168. See, e.g., Colorado v. New Mexico, 459 U.S. 176 (1982); Nebraska v. Wyoming, 325 U.S. 589 (1945); Washington v. Oregon, 297 U.S. 517 (1936).

169. See Washington, 297 U.S. at 520, 527; Nebraska, 325 U.S. at 617. 
Colorado were diverting an excessive amount of the North Platte River and depriving Nebraska of its water. ${ }^{170}$ One issue in this case, which is applicable to international situations, is that the states had different state law dealing with surface water rights, forcing the Court to decide which law to apply. ${ }^{171}$ When states follow the same law, the law can be applied by the courts, but in situations like the one in Nebraska, a compromise must be reached. ${ }^{172}$

Until recently, almost all interstate water cases involved surface water. ${ }^{173}$ One early case brought shared groundwater to the Court's attention. ${ }^{174}$ In Washington, the Court held that "the right to pump in reasonable quantities for the beneficial enjoyment of the overlying land is allowed." 175 The Court based its decision on local geology to determine how the subterranean water flowed without the effects of pumping, stating that their decision might be different with varying groundwater characteristics. ${ }^{176}$

More recent interstate groundwater cases have centered on one state or private party purchasing water for export outside the selling state's boundaries. ${ }^{177}$ The Court in Sporhase held that groundwater is an article of commerce and is subject to congressional regulations. ${ }^{178}$ The Court used the example of the Ogallala aquifer, which is shared by several states, and the scarcity of water in certain areas to demonstrate the federal interest in water. ${ }^{179}$ As an article of commerce, a state cannot deny exportation of water to another state unless it can put forth a statute that "regulates evenhandedly to effectuate a legitimate local public interest, ... its effects on interstate commerce are only incidental," and the burden to commerce is not excessive. ${ }^{180}$

Nebraska's stated purpose was "to conserve and preserve diminishing sources of ground water." ${ }^{\text {"181 }}$ The Court found this purpose legitimate but not sufficient to pass constitutional muster because of the excessive burden the statute imposed. ${ }^{182}$ In dicta, Justice Stevens stated the Court's hesitancy to hinder a state's effort to conserve a vital resource and made the distinction between economic protectionism and health and safety issues. ${ }^{183}$ Similar issues

170. Nebraska, 325 U.S. at 591-92.

171. Id. at 599-600.

172. Compare Wyoming v. Colorado, 259 U.S. 419, 424 (1922) (providing an example of competing states that have the same state law regarding water), with Nebraska, 325 U.S. at 599-600 (providing an example of competing states with different legal frameworks).

173. See Sporhase v. Nebraska ex rel. Douglas, 458 U.S. 941 (1982) (demonstrating the increase in interstate groundwater cases); City of El Paso v. S.E. Reynolds, 563 F. Supp. 379 (D.N.M. 1983).

174. See Washington, 297 U.S. at 517.

175. Id. at 525 .

176. Id.

177. See Sporhase, 458 U.S. at 944-45; City of El Paso, 563 F. Supp. at 381.

178. Sporhase, 458 U.S. at $953-54$.

179. Id. at 953.

180. Id. at 954 (quoting Pike v. Bruce Church Inc., 397 U.S. 137, 142 (1970)).

181. Id.

182. Id. at $954-58$.

183. Id. at 956 . 
might be seen in the future in an international context. ${ }^{184}$ Although the Commerce Clause is only enforceable within the United States, the reasoning expressed in Sporhase could be applied to internationally shared groundwater. ${ }^{185}$

Another source of interstate agreements is legislation generated from the European Economic Community (EEC). ${ }^{186}$ The EEC has enacted shared natural resources legislation to protect and conserve the environment including groundwater. ${ }^{187}$ Directives focus on an open exchange of information and assessment triggered by the impact on one state's resources based on the actions of another state. ${ }^{188}$ Enforcement is achieved through a committee comprised of members jointly appointed by all affected states. ${ }^{189}$

Evaluating how courts have dealt with groundwater issues generates another brick in the foundation of future policy, but many courts have not yet had to deal with these issues. ${ }^{190}$ Other multidisciplinary groups, comprised of scientists and legal scholars, have been assessing future problems and recommending factors for future working agreements. ${ }^{191}$ Although these groups may not be creating enforceable policy, the fruits of their cooperative efforts are still important. ${ }^{192}$

\section{c. Nongovernmental and Intergovernmental Agencies}

Although most water law has been created through treaties and agreements in response to a shared water resource, the role of nongovernmental and intergovernmental agencies should not be underestimated in the evolution of international water law. ${ }^{193}$ Two organizations, in particular, should be noted. ${ }^{194}$ The first of these is the International Law Commission (ILC), a group of elected members assembled by the UN in $1947 .{ }^{195}$ In 1970 , the UN directed the ILC to examine nonnavigational uses of watercourses with the objective of codifying a progressive

184. See generally id. at $954-58$ (discussing economic protectionism and health and safety issues).

185. See U.S. CONST. art. I, § 8, cl. 3; Sporhase, 458 U.S. at 954-58.

186. See Stefano Burchi, Shared Natural Resources in the European Economic Community Legislation, in TRANSBOUNDARY RESOURCES LAW 77 (Albert E. Utton \& Ludwik A. Teclaff eds., 1987).

187. Id. at 78 .

188. Id. at 79 .

189. Id. at 82 .

190. See, e.g., Colorado v. New Mexico, 459 U.S. 176 (1982); Nebraska v. Wyoming, 325 U.S. 589 (1945); Washington v. Oregon, 297 U.S. 517 (1936).

191. See Robert D. Hayton, The Law of International Aquifers, 22 NAT. RESOURCES J. 71, 73, 80 (1982).

192. See id.

193. See Caponera \& Alheritiere, supra note 18, at 589, 590-91.

194. See id. at 589-94; Shashank Upadhye, The International Watercourse: An Exploitable Resource for the Developing Nation Under International Law?, 8 CARDOZO J. INT'L \& COMP. L. 61, 74 (2000).

195. McCaffrey, supra note 8, at 150. 
level of international law. ${ }^{196}$ Although the ILC has helped create guidelines for water law, originally its limited scope excluded groundwater. ${ }^{197}$ This has recently been modified to a broader definition of a water basin that explicitly includes certain types of groundwater. ${ }^{198}$ The second agency worth noting is the group of scholars in the International Law Association (ILA), a "major international nongovernmental organization devoted to international legal matters." 199

The ILA is responsible for some of the earliest efforts to address shared groundwater issues. ${ }^{200}$ This has been accomplished through a series of conferences generating guidance rules, which are promulgated as a fall-back for states that did not have their own rules. ${ }^{201}$ The first of these are the Helsinki Rules, created in $1966 .{ }^{202}$

The Helsinki Rules are significant to the evolution of international water policy for several reasons and form the basis of many international water agreements. ${ }^{203}$ The first important feature of the Rules was their emphasis on the "unity of the drainage basin" when creating an agreement. ${ }^{204}$ This is valuable because Article II specifically includes groundwater by defining an international drainage basin as a "geographical area extending over two or more States determined by the watershed limits of the system of waters, including surface and underground waters, flowing into a common terminus." 205 Although it is unlikely that the rule makers were focused on Article II's applicability to groundwater, ${ }^{206}$ its inclusion is now viewed as a landmark for the development of international groundwater law theory. ${ }^{207}$

Another important aspect of the Rules is that they were formed under a theory of "equitable utilization," stating that each state was entitled to a "reasonable and equitable share in the beneficial uses of the waters." 208 The ILA did not define a reasonable and equitable share and instead recommended

196. Hayton, supra note 191, at 80 .

197. Caponera \& Alheritiere, supra note 18 , at $589,591$.

198. United Nations Convention on the Law of Non-Navigational Uses of International Watercourses, G.A. Res. 51/229, U.N. GAOR, 51st Sess., at art. 2, U.N.Doc. A/RES/51/229 (1997) available at http://www.un.org/ga/documents/gares51/ga51-229.htm (last visited Dec. 22, 2003) [hereinafter Watercourse Convention].

199. Hayton, supra note 191, at 73.

200. Eckstein \& Eckstein, supra note 57, at 228.

201. Hayton, supra note 191, at 73 n.2.

202. Int'l Law Ass'n, The Helsinki Rules on the Uses of the Waters of International Rivers (1967), available at $\mathrm{http}: / / \mathrm{www}$. internationalwaterlaw.org/IntlDocs/Helsinki_Rules.htm(last visited Sept. 19, 2003) [hereinafter Helsinki Rules].

203. Itzchak E. Kornfeld, A Water Solution for the Middle East Conflict, 33 ENVTL. L. REP. 10207 (2003).

204. See Caponera \& Alheritiere, supra note 18 , at 619.

205. Helsinki Rules, supra note 202, at art. II.

206. Hayton, supra note 191, at 74.

207. See McCaffrey, supra note 8, at 141-44.

208. Helsinki Rules, supra note 202, at art. IV. 
decisions be made on a case-by-case basis "in the light of all the relevant factors." 209 In practice, equitable utilization means that a user can utilize a resource so long as it does not harm another user who is sharing the resource. $^{210}$ Intrinsic in this is the need for flexibility and cooperation of users. ${ }^{211}$

After the formation of the Helsinki Rules, the ILA created a Committee on International Water Resources Law. ${ }^{212}$ This group has continued to develop concepts of international groundwater law by creating guidance rules. ${ }^{213}$ The Seoul Conference of 1986 confirmed the ideas of the Helsinki Rules and expanded them further to include all types of aquifers. ${ }^{214}$ The ILC was reconvened in 1991 and has been striving to update the Helsinki and Seoul Rules. $^{215}$

The broad definition of an international drainage basin as outlined by the Helsinki Rules has been a source of much debate. ${ }^{216}$ The ILC, for example,

209. Id. at art. V. Although the Rules did not define equitable share, it did provide a noncomprehensive list of factors that should be considered to assist in its determination. Id. These include the following:

1. The geography of the basin, including in particular the extent of the drainage area in the territory of each basin State;

2. The hydrology of the basin, including in particular the contribution of water by each basin State;

3. The climate affecting the basin;

4. The past utilization of the waters of the basin, including in particular existing utilization;

5. The economic and social needs of each basin State;

6. The population dependent on the waters of the basin in each basin State;

7. The comparative costs of alternative means of satisfying the economic and social needs of each basin State;

8. The availability of other resources;

9. The avoidance of unnecessary waste in the utilization of waters of the basin;

10. The practicability of compensation to one or more of the co-basin States as a means of adjusting conflicts among uses; and

11. The degree to which the needs of a basin State may be satisfied, without causing substantial injury to a co-basin State.

Id. at art. $\mathrm{V}(\mathrm{II})$.

210. Kornfeld, supra note 203, at 10207.

211. Id.

212. Hayton, supra note 191, at 78.

213. See McCaffrey, supra note 8, at 141-50.

214. Eckstein \& Eckstein, supra note 57, at 228-29. This inclusion of all types of aquifers is accomplished by no longer requiring a connection between the surface and groundwater as required under the Helsinki Rules. Compare Helsinki Rules, supra note 202, at art. II (describing the ILA's previous stance excluding hydraulically unrelated aquifers), with Int'l Law Ass'n, The Seoul Rules on the Uses of the Waters of International Rivers, art. I \& II (1986) (deciding to include hydraulically unrelated aquifers), available at http://www.internationalwaterlaw.org/IntlDocs/SeoulRules.htm (last visited Mar. 26, 2003). This allows an aquifer that crosses an international boundary, which exists totally independent of surface water to qualify as an international aquifer. $I d$.

215. Int'l Law Ass'n, New Delhi Conference (2002): Water Resources Committee, available at http://www.ila-hq.org/html/layout_committee.html (last visited Mar. 28, 2004).

216. Hayton, supra note 191, at 80-81. 
originally refused to extend the definition to include the overlying territory in an attempt to limit what would be governed by international law. ${ }^{217}$ In 1980, the ILC's draft articles contained a note that stated: "A watercourse system is formed of hydrographic components such as rivers, lakes, canals, glaciers and groundwater ...."218 Although this was an important step, the draft articles themselves made no mention of groundwater. ${ }^{219}$ The ILC finally agreed with the ILA's inclusion of groundwater in the definition of watercourse at its 1997 Convention on the Non-Navigational Uses of International Watercourses, but the ILC's scope remains more narrow than the that of the ILA. ${ }^{220}$

Several other important recommendations were made by the Watercourse Convention. ${ }^{221}$ Similar to the Helsinki Rules, the Convention emphasized the need for equitable use in an attempt to attain "optimal and sustainable utilization." 222 Cooperation was also emphasized by this and the earlier Mar del Plata Conference in 1977. ${ }^{223}$ At Mar del Plata, the ILC recommended that “ "countries sharing water resources ... should review existing and available techniques for managing shared water resources and cooperate in the establishment of programs, machinery and institutions necessary for the coordinated development of such resources." "224 The theory of "no substantial harm" was also included. ${ }^{225}$

217. Dante A. Caponera, Patterns of Cooperation in International Water Law: Principles and Institutions, in Transboundary Resources LAW 1, 4 (Albert E. Utton \& Ludwik A. Teclaff eds., 1987).

218. Hayton, supra note 191, at 84 (alteration in original) (quoting Report of the International Law Commission on the Work of its Thirty-Second Session, 35 U.N. GAOR, 32d Sess., Supp. No. 10 at 247, U.N. Doc. A/35/10 (1980) [hereinafter Thirty-Second Session]).

219. Id.

220. Watercourse Convention, supra note 198. Although the definition of an international watercourse was expanded, it still does not include confined transboundary aquifers, which are aquifers that are not related to any surface water body. Stephen McCaffrey, The Contribution of the UN Convention on the Law of the Non-Navigational Uses of International Watercourses, 1 INT'L J. GLOBAL ENVTL. ISSUES 250, 251 (2001), available at http://www.internationalwaterlaw.org (last modified Nov. 2, 2003). An ILC resolution encourages states to apply the principles enumerated in the draft articles to isolated aquifers. Id.

221. See Watercourse Convention, supra note 198.

222. Id. at art. V. In defining reasonable and equitable use, the convention created their own list of factors that should be considered. Id. These factors are as follows:

(a) Geographic, hydrographic, hydrological, climatic, ecological and other factors of a natural character; (b) The social and economic needs of the watercourse States concerned; c) The population dependent on the watercourse in each watercourse State; (d) The effects of the use or uses of the watercourses in one watercourse State on other watercourse States; (e) Existing and potential uses of the watercourse; (f) Conservation, protection, development and economy of use of the water resources of the watercourse and the costs of measures taken to that effect; (g) The availability of alternatives, of comparable value, to a particular planned or existing use. Id. at art VI.

223. Caponera \& Alheritiere, supra note 18, at 614 (citing Report of the United Nations Water Conference, Mar del Plata Conference, at 53, U.N. Doc. E/Conf.70/CBP/1 (1977)).

224. Id. (alteration in original).

225. Watercourse Convention, supra note 198 ("Watercourse States shall, in utilizing an international watercourse in their territories, take all appropriate measures to prevent the causing of significant harm to other watercourse States."). 
Another UN organization worth noting is the Economic Commission for Europe (UNECE). The UNECE has "adopted a number of declarations, decisions, and recommendations concerning fresh water." ${ }^{226}$ Many of these include groundwater. ${ }^{227}$ Much of the UNECE's work focuses on groundwater pollution, including the Declaration of Policy on Prevention and Control of Water Pollution, Including Transboundary Pollution. ${ }^{228}$ Some of the UNECE's water usage efforts include the 1984 Declaration of Policy on the Rational Use of Water, which echoes many of the sentiments of the Helsinki Rules and other international recommendations. ${ }^{229}$ This declaration recognized the interconnected nature of surface water and groundwater and encouraged "a unified strategy" for dealing with water issues and "co-ordinated utilization." 230 A later recommendation stated that any coordinated water-use efforts by riparians must include a joint plan for the entire basin, once again emphasizing the need for the integrated treatment of surface and groundwater. ${ }^{231}$

In 1992, the UNECE created the Convention on the Protection and Use of Transboundary Watercourses and International Lakes. ${ }^{232}$ This convention, ratified by European countries and the Russian Federation, ${ }^{233}$ encourages monitoring, research, cooperative interactions, including exchange of information and mutual assistance, institutional arrangements, and public access to information. ${ }^{234}$ With the ultimate goal of sustainable development, participating countries "manage current environmental resources in a manner that satisfies current demand without compromising the needs of future generations." 235

Although the rules and guidance generated from nongovernmental agencies are important steps in the recognition of groundwater resources, a question is raised regarding their binding nature. ${ }^{236}$ Because the ILA is a nongovernmental organization that requires no public participation, any rules

226. McCaffrey, supra note 8, at 161-62.

227. Id.

228. Id. at 162 .

229. Id.

230. Id.

231. Id. at $162-63$.

232. United Nations Economic Comm. for Europe, Convention on the Protection and Use of Transboundary Watercourses and International Lakes, at $\mathrm{http}: / / \mathrm{www} . u n e c e . o r g / \mathrm{env} / \mathrm{water} / \mathrm{welcome.html}$ (last visited Mar. 29, 2004).

233. United Nations Economic Comm. for Europe, Convention on the Protection and Use of Transboundary Watercourses and International Lakes: Status of Ratification of Water Convention, at http://www.unece.org/env/water/status/lega_wc.htm (last visited Mar. 29, 2004).

234. United Nations Economic Comm. for Europe, supra note 233.

235. Chris Hudson, The Role of International Environmental Law in the Protection of the Danube River Basin: The Baia Mare Cyanide Spill, 12 Colo. J. InT'L ENVTL. L. \& POL'Y 367, 385 (2001).

236. See Jordan C. Kahn, 1997 United Nations Convention on the Law of Non-Navigational Uses of International Watercourses, 1996-1998 Colo. J. INT'L ENVTL. L. \& POL'Y Y.B. 178 (1997). 
created by it are not considered binding international law. ${ }^{237}$ The ILC's guidance is slightly more binding because it is made up of member states. ${ }^{238}$ The 1997 Articles will become binding on those states who choose to sign and ratify the Convention, but no state is required to sign. ${ }^{239}$ It is possible that even states that do not sign the Convention will be bound "if it represents customary international law." 240 Regardless of whether the ILA or the ILC rules are binding, the seemingly universal ideas of scholars that have continued to appear, including equitable resource use, cooperation, and the broad definition of a water drainage system, should be included in any future international groundwater policy. ${ }^{241}$

\section{Examples of Existing Groundwater Agreements and Treaties}

Once the possible issues that should be considered are understood, it is useful to examine how they have been applied by past water treaties. ${ }^{242}$ Although international groundwater agreements are rare, a few agreements and proposals serve as a helpful basis for understanding important factors for a successful policy. ${ }^{243}$ Existing or model agreements place ideas into a workable structure that can be used by other countries. ${ }^{244}$ In addition, their weaknesses can be avoided, allowing for policy evolution. ${ }^{245}$

\section{a. Franco-Swiss Genevese Aquifer Agreement}

One of the most successful examples of shared groundwater policy is the agreement between France and Switzerland regarding the Lake Geneva Basin groundwater. ${ }^{246}$ This 1978 agreement was formed in response to a water shortage caused by the over-pumping of the nineteen kilometer aquifer. ${ }^{247}$ The countries were forced to consider solutions when extraction exceeded natural recharge. ${ }^{248}$ Proposed alternatives included reducing withdrawals by supplementing the groundwater supply from other sources and enhancing

237. Melvin Woodhouse, Is Public Participation a Rule of the Law of International Watercourses?, 43 NAT. RESOURCES J. 137, 175 (2003).

238. Kahn, supra note 236, at 178.

239. Id. at 183.

240. Id.

241. See Upadhye, supra note 194, at 69-83.

242. See, e.g., Robert D. Hayton \& Albert E. Utton, Transboundary Groundwaters: The Bellagio Draft Treaty, 29 NAT. RESOURCES J. 663 (1989); Wohlwend, supra note 61.

243. See Hayton \& Utton, supra note 242; Wohlwend, supra note 61.

244. Hayton \& Utton, supra note 242; Wohlwend, supra note 61.

245. See, e.g., Hayton \& Utton, supra note 242; Wohlwend, supra note 61.

246. Eckstein \& Eckstein, supra note 57, at 227.

247. Wohlwend, supra note 61 , at 2 .

248. Id. 
natural recharge. ${ }^{249}$ A preliminary test of the latter failed, leading to negotiations between the State of Geneva and the French Department of Haute-Savoie. ${ }^{250}$ The result was one of the oldest and most successful groundwater treaties. ${ }^{251}$

One important aspect of this agreement is that it was formed as a "regional arrangement between the competent local authorities." 252 Another important feature is the creation of a six-member commission composed of three members appointed by each participating country. ${ }^{253}$ At least two of the three appointees must be water specialists. ${ }^{254}$ The purely consultative commission meets twice yearly, alternating meeting locations between Switzerland and France. ${ }^{255}$ The commission has the manifold task of providing technical expertise, creating an annual plan for aquifer use, and proposing groundwater protection measures. ${ }^{256}$ All decisions are recorded and presented to the reining authority at each respective country. ${ }^{257}$ Water extraction and recharge are also monitored and metered by the local authorities. ${ }^{258}$ Future annual water needs are determined by users submitting their pumping requirements to their commissions, who are then given extraction permits. ${ }^{259}$ Operation and maintenance costs are shared by the two countries. ${ }^{260}$ This accord provides guidance for future treaties by presenting an example of a workable agreement. ${ }^{261}$

\section{b. Bellagio Draft Treaty}

The Bellagio Draft Treaty is a model agreement inspired by the water situation along the Mexico-United States border and can be used by countries seeking to create international water policy. ${ }^{262}$ "The overriding goal of the draft treaty is to achieve joint, optimum utilization of the available waters, facilitated by procedures for avoidance or resolution of differences over shared

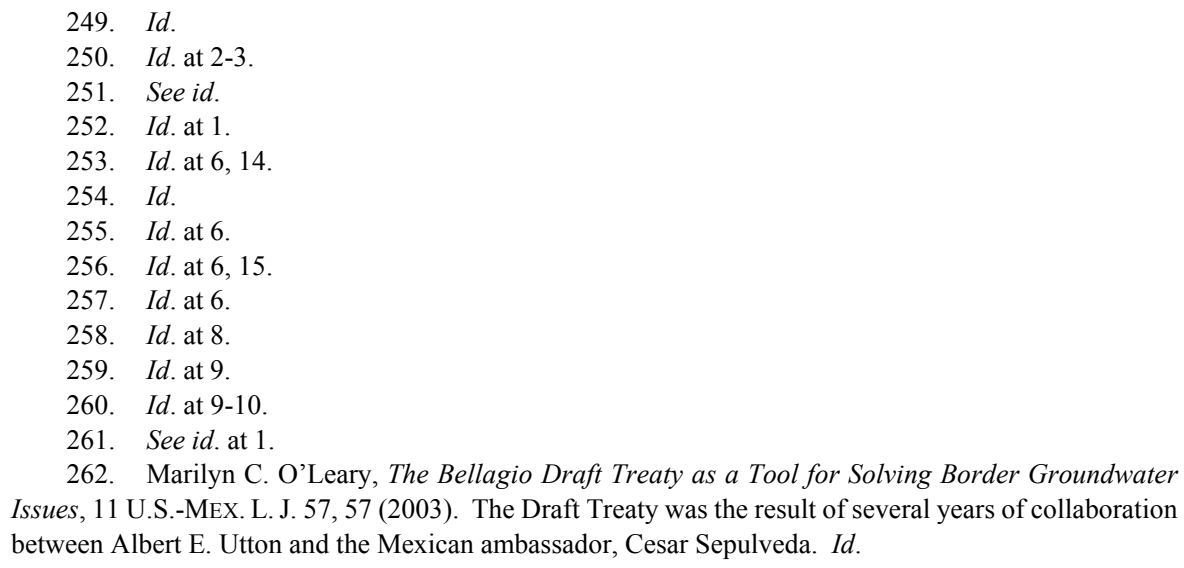

262. Marilyn C. O'Leary, The Bellagio Draft Treaty as a Tool for Solving Border Groundwater Issues, 11 U.S.-MEX. L. J. 57,57 (2003). The Draft Treaty was the result of several years of collaboration between Albert E. Utton and the Mexican ambassador, Cesar Sepulveda. Id. 
groundwaters in the face of the ever increasing pressures on this priceless resource." $" 263$

The Bellagio Draft Treaty contains twenty articles with guidance for a cooperative agreement of a shared groundwater resource. ${ }^{264}$ Similar to the concepts laid forth by the Convention on the Non-Navigational Uses of International Watercourses and the Helsinki Rules, the Bellagio Draft Treaty is based on the theory of reasonable and equitable use to achieve optimum utilization. ${ }^{265}$ To achieve this, the treaty contains guidance for water quality protection, preparation of management plans, a drought management plan, and dispute resolution. ${ }^{266}$

Perhaps most helpful to the management of such an agreement, the draft treaty details requirements for a commission to monitor the aquifer. ${ }^{267}$ Similar to the existing Franco-Swiss agreement, the commission would create and maintain a detailed database with hydrologic parameters, aquifer level, and water quality. ${ }^{268}$ In addition to aquifer management, tasks of the commission include budget preparation, declaring transboundary groundwater conservation areas, drought alerts, and plan implementation. ${ }^{269}$ The draft treaty, adopted at the Sixth Congress of the International Water Resources Association in Ottawa in 1988, creates useful guidelines for some important factors in the formation of international agreements. ${ }^{270}$

\section{EXAmining the Water Situation Along the U.S.-MeXico Border}

Although water conflicts exist all over the world, the threat of a water crisis is particularly high along the U.S.-Mexico border because of the arid climate and increasing population. ${ }^{271}$ Population estimates of border counties are as high as twelve million residents. ${ }^{272}$ Predictions of population growth estimate that this will double by $2020 .{ }^{273}$

The United States and Mexico share at least eighteen groundwater sources. ${ }^{274}$ Potential water disputes between the United States and Mexico began with the secession of the southwest in 1848, because any boundary

263. Hayton \& Utton, supra note 242, at 665.

264. Id. at 677-721.

265. See id. at 665.

266. Id. at $677-721$.

267. Id. at $684-88$.

268. Id. at 688-91.

269. Id. at 684-87.

270. Wohlwend, supra note 61 , at 5 .

271. Irasema Coronado, Water Conflict in the Borderlands, 7 BORDERLINES 57, 9 ๆ 1-2 (July 1999), at http://www.americaspolicy.org/borderlines/1999/b157.b157oview_body.html. (last visited Mar. 29, 2004).

272. Vivienne Bennett \& Lawrence A. Herzog, U.S.-Mexico Borderland Water Conflicts and Institutional Change: A Commentary, 40 NAT. ResourCES J. 973, 973-74 (2000).

273. Id. at 974.

274. See Mumme, supra note 17, at 344, 363-77. 
agreement separating the land also separates the water. ${ }^{275}$ Of these, none are governed by an official binational agreement. ${ }^{276}$ Many of these aquifers have the added complication of being shared by more than one state, as well as by both nations. ${ }^{277}$ Water concerns have become particularly confusing as water needs along the border increase. ${ }^{278}$ Better technology enhances understanding and increases a city's ability to create effective change based on increased understanding. ${ }^{279}$

In addition to technical difficulties, several other barriers to negotiations between the United States and Mexico are evident. ${ }^{200}$ These barriers include an excess of governmental agencies, cultural differences, language barriers, and "dramatically different forms of government and notions of politics."281 These differences aside, the shared use of rivers, aquifers, and watersheds, as well as increased trade and the practical dissolution of the border between the two countries, compel communication and understanding for any water agreements. ${ }^{282}$

\section{A. El Paso and Ciudad Juarez: A Case Study}

The scarcity of available water along the border can be seen in many locations, but perhaps the best example is El Paso and Ciudad Juarez. ${ }^{283}$ The combination of the arid climate and rapidly increasing population creates serious future water concerns. ${ }^{284}$ Together, the two cities accommodate two million residents, a number which increased sixty-three percent in Ciudad Juarez and thirty-four percent in El Paso between 1980 and 1994 and continues to grow. ${ }^{285}$ Population growth upstream creates an additional demand on surface water and decreases the quantity available for El Paso. ${ }^{286}$

The United States Department of Agriculture estimates that the drought in the Rio Grande basin started in 1993. ${ }^{287}$ “ '[D]rought' means a moisture deficit bad enough to have social, environmental or economic effects." 288 The

275. Hall, supra note 13, at 866 .

276. Mumme, supra note 17, at 363-77.

277. Id.

278. Hall, supra note 13, at 866 .

279. See id. at 868 .

280. See Bennett \& Herzog, supra note 272, at 978-79.

281. Id. at 978 .

282. Elaine Moore Hebard, A Focus on a Binational Watershed with a View Toward Fostering A Cross-Border Dialogue, 40 NAT. ResourCEs J. 281, 283-84 (2000); Bennett \& Herzog, supra note 272, at 978-80.

283. See Hall, supra note 13, at 867 . Other examples of cities with shared water are Laredo/Nuevo Laredo, San Diego/Tijuana, and Ambos Mexico. Id.

284. Chavez, supra note 1, at 237-38.

285. Id.

286. Walton \& Ohlmacher, supra note 111 , at 7.

287. O'Leary, supra note 262, at 59.

288. David Miskus, U.S. Drought Monitor, at http://www.drought.unl.edu/dm/archive/99/classify 
drought in the lower Rio Grande Valley is currently categorized as extreme. ${ }^{289}$ Evaluating water issues faced by these two cities and their solutions provide important information for future groundwater issues faced in other locations along the border. ${ }^{290}$

El Paso and Juarez share the Rio Grande River, the Hueco Bolson aquifer, and the Mesilla Bolson aquifer for their water needs. ${ }^{291}$ In the past, the Rio Grande River and shallow wells have been the primary source of water. ${ }^{292}$ As local population has grown, so has the dependence on groundwater. ${ }^{293}$ Although the two cities account for eighty percent of the groundwater usage, local farms and military installations also mine the resource. ${ }^{294}$ In general, the United States is able to fulfill all its water needs while the majority of citizens of the Mexican colonias often do not meet their daily needs. ${ }^{295}$

The primary source of groundwater is the Hueco Bolson aquifer, which is being depleted by both El Paso and Ciudad Juarez. ${ }^{296}$ Increased dependence on groundwater by both sides of the border creates the potential for conflict because the only legal framework for water allocation involves surface water. ${ }^{297}$ No existing agreement for groundwater is in effect. ${ }^{298}$

Several measures have been put into place on both sides of the border to prolong a water crisis. ${ }^{299}$ One way El Paso is attempting to create sustainability is to reduce usage and reroute irrigation water and use it for municipal purposes. ${ }^{300}$ El Paso has also increased its dependence on surface water by piping water from Elephant Butte Dam. ${ }^{301}$ In September 2002, El Paso improved its ability to treat Rio Grande water by expanding a water treatment facility, increasing treatment capacity from forty to sixty million gallons per day. ${ }^{302}$

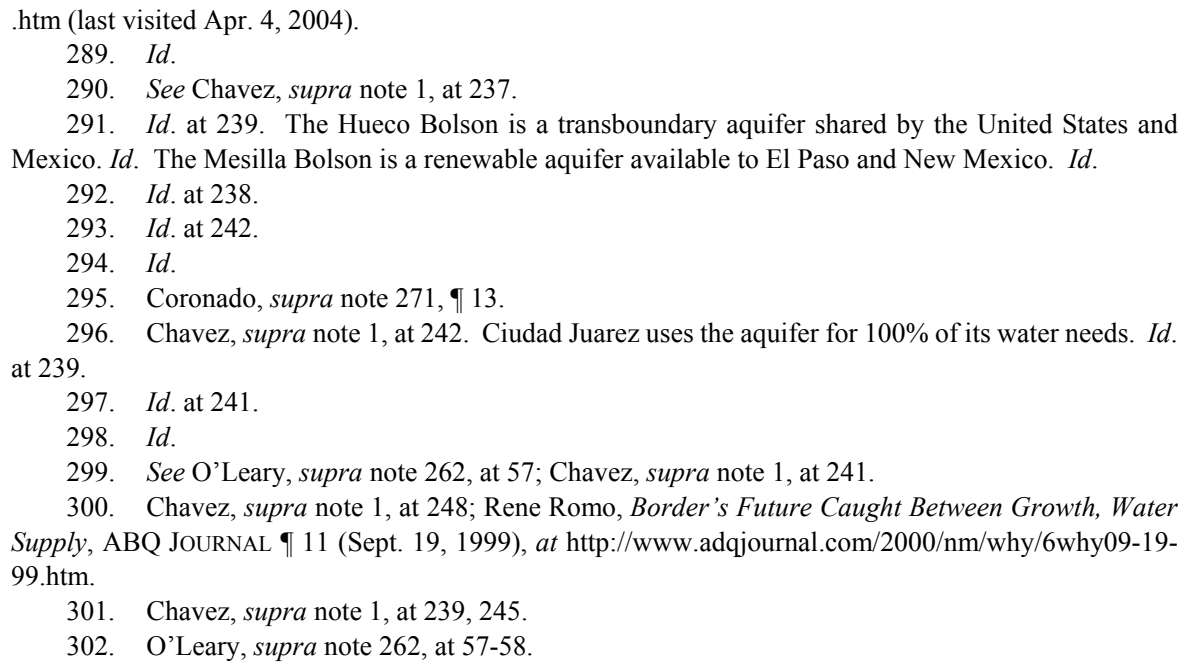


Increased usage of surface water, particularly the Rio Grande, creates only a temporary fix and can generate greater long-term problems. ${ }^{303}$ The Rio Grande is a losing stream, meaning that the groundwater is recharged in part by stream flow. ${ }^{304}$ A greater reliance on surface water can decrease the water available in the aquifer. ${ }^{305}$ Excessive pumping can increase its salinity, making the water less potable. ${ }^{306}$

On the other side of the border, Juarez plans to use some of its annual Rio Bravo allocation of 60,000 acre-feet for municipal purposes to alleviate the burden on the Rio Grande. ${ }^{307}$ One of Juarez's biggest challenges is the infrastructure of the utility system. ${ }^{308}$ Many of the systems are broken down and little policy support is found. ${ }^{309}$ Up to thirty percent of Juarez's water usage is lost through broken pipes and never reaches its inhabitants. ${ }^{310}$

Although no law governing the groundwater shared by these two cities has been created, efforts are being made to work together for sustainability. ${ }^{311}$ Joint projects have been useful in understanding each city's dependence on water sources and the development of usage plans. ${ }^{312}$ City governments' planning efforts have been assisted by the IBWC. ${ }^{313}$

\section{B. International Boundary and Water Commission}

The IBWC is the governing agency relied upon by both Mexico and the United States to monitor international boundary water and settle disputes of its use along the 2,000 mile United States-Mexico border. ${ }^{314}$ Although this agency has been functioning for over one hundred years, it received little attention until recently when water issues became a growing concern. ${ }^{315}$

The IBWC has a broad range of dispute resolution responsibilities including "domestic, municipal, agricultural, and industrial water supplies; ... . fish and wildlife and recreation; ... floods and drought; . . pollution; and ... land use and environmental relationships." 316 Although in the past the

303. See Walton \& Ohlmacher, supra note 111, at 3.

304. Id.; see note 111 and accompanying text.

305. See Walton \& Ohlmacher, supra note 111, at 3.

306. Id.

307. O'Leary, supra note 262, at 58.

308. See Chavez, supra note 1 , at 246.

309. Id.

310. Id.

311. See id. at $248-50$.

312. Id.

313. Id. at 250 .

314. Stephen P. Mumme \& Scott T. Moore, Agency Autonomy in Transboundary Resource Management: The United States Section of the International Boundary and Water Commission, United States and Mexico, 30 NAT. ResourCES J. 661, 661 (1990). The IBWC consists of a Mexican and American section. Marin, supra note 16, at 35 .

315. Dworsky \& Utton, supra note 134, at 413.

316. Id. at 414 . 
Commission only oversaw surface water use, it has the potential to monitor groundwater issues for shared aquifers. ${ }^{317}$

Treaty enforcement is also a responsibility of the IBWC. ${ }^{318}$ The United States has frequently violated treaty provisions regarding dispute resolutions creating a viewed attitude of moral superiority. ${ }^{319}$ Mexico has also had problems meeting its water obligations as defined by the 1944 treaty. ${ }^{320}$

On a regional level, the formation of consejos de cuencas is another method of water resource planning. ${ }^{321}$ These regional watershed councils have been used by government agencies in border locations to create a local approach to a problem. ${ }^{322}$ The 1944 Water Treaty gave the IBWC the lead role and "a virtual monopoly on agreements dealing with transboundary water management." 323 Therefore, these groups would create a plan and then work with the agency for its implementation. ${ }^{324}$ Although the IBWC has not yet created a groundwater agreement, recent working groups and policy discussions indicate that the future of the IBWC will include groundwater. ${ }^{325}$

\section{Existing Water Agreements Along the U.S.-Mexico Border}

Although no formal groundwater accords between the United States and Mexico have been created, several important agreements pertaining to surface water and environmental concerns are in place. ${ }^{326}$ These should be understood because of the effect they may have on groundwater. ${ }^{327}$ Surface water

317. Chavez, supra note 1, at 241-42.

318. Dworsky \& Utton, supra note 134, at 441.

319. Id.

320. Jill Warren, Mexico's Compliance with the 1994 Water Treaty Between the United States and Mexico: A Texas Perspective, 11 U.S.-MEX. L.J. 41, 42 (2003).

321. Christopher P. Brown \& Stephen Mumme, Applied and Theoretical Aspects of Binational Watershed Councils (Consejos de Cuencas) in the U.S.-Mexico Borderlands, 40 NAT. RESOURCES J. 895, 904-05 (2000).

322. Id.

323. Stephen P. Mumme, Reinventing the International Boundary and Water Commission, BORDERLINES 79 - 4 (July 2001), available at http://www.americaspolicy.org/borderlines. On February 3, 1944, the United States and Mexico signed the Treaty Relating to the Utilization of Waters of the Colorado and Tijuana Rivers and of the Rio Grande. Alberto Szekely, How to Accommodate an Uncertain Future into Institutional Responsiveness and Planning: The Case of Mexico and the United States, 33 Nat. RESOURCES J. 397, 397 (1993). This agreement defines the equitable distribution of the Rio Grande River from Fort Quitman, Texas to the Gulf of Mexico and broadened the powers of the IWBC. Id.; Warren, supra note 320 , at 41 .

324. See Brown \& Mumme, supra note 321, at 910-11.

325. Mumme, supra note 323, ๆ 19-20.

326. See Szekely, supra note 323, at 397 . The first bilateral water agreement was formed through a convention in 1889. Id. In 1906, the Convention created an agreement to provide equitable distribution of Rio Grande water for irrigation. Id.

327. See Mumme, supra note 17, at 346. 
agreements can also form a basis on which future groundwater agreements can be created. ${ }^{328}$

Two types of agreements can be created: formal and informal. ${ }^{329}$ Formal agreements consist of treaties or memorandas of agreement between two nations. ${ }^{330}$ These often create agencies such as the IBWC to assist in enforcement and conflict resolution. ${ }^{331}$ Informal accords involve meetings of regional officials and nonbinding agreements. ${ }^{332}$ Both types are important elements of a cooperative effort to share a resource equitably. ${ }^{333}$

\section{Minute 242}

The closest approximation to an existing groundwater agreement along the U.S.-Mexico border is Minute 242. ${ }^{334}$ Minute 242 was signed in 1973 in an effort to recognize the need for a groundwater agreement between the United States and Mexico. ${ }^{335}$ Clause six requires the United States and Mexico to consult with each other "prior to undertaking any new development of either the surface or the groundwater resources, or undertaking substantial modifications of present developments, in its own territory in the border area that might adversely affect the other country." "336 The agreement also limits groundwater pumping until a comprehensive agreement is created. ${ }^{337}$ Minute 242 was an important step in the creation of further regulation, but little advancement has been made since its inception. ${ }^{338}$

\section{La Paz Agreement}

The 1983 Border Environment Cooperation, or "La Paz" Agreement, is an important example of a bilateral agreement creating an ongoing dialogue. ${ }^{339}$ The environmental plan, created at the request of President George Bush and President Salinas, consists of a series of timed stages and covers a range of

328. See id.

329. Bennett \& Herzog, supra note 272, at 976.

330. Id.

331. See id.

332. Id.

333. See id. at $976-80$.

334. See Int'1 Boundary \& Water Comm'n, Minute 242: Permanent and Definite Solution to the International Problem of the Salinity of the Colorado River (Aug. 30, 1973), available at http://www.usbr. gov/lc/region/pao/pdfiles/min242.pdf[hereinafter Minute 242]. A "Minute" is an agreement reached by the Commission and submitted to both governments for approval. Szekely, supra note 323, at 398.

335. Mumme, supra note 17 , at 341.

336. Minute 242, supra note 334.

337. Id.

338. See Robert Emmet Clark, Institutional Alternatives for Managing Groundwater Resources: Notes for a Proposal, 18 NAT. RESOURCES J. 158 (1978); Mumme, supra note 17, at 341.

339. Mumme, supra note 17, at 355. 
environmental topics including water. ${ }^{340}$ Although the agreement did not specifically mention groundwater, it has been applied to groundwater in some cases. ${ }^{341}$ The agreement has given rise to several plans and working groups to protect the environment along the border. ${ }^{342}$ The La Paz agreement is a good example of what can be accomplished through cooperation. ${ }^{343}$

\section{North American Free Trade Agreement Side Accord}

A thorough discussion of water issues between the United States and Mexico must include NAFTA. ${ }^{344}$ The trade increase generated by NAFTA reduces the divisibility power of the border and increases water consumption and potential pollution. ${ }^{345}$ NAFTA is also important in a water context because of the Environmental Side Agreement. ${ }^{346}$

Until 1995, the United States and Mexico operated according to the Integrated Environmental Border Plan (IEBP), which expressed a joint commitment to protect and improve the environmental quality of the borderlands. ${ }^{347}$ After January 1995, environmental issues have been addressed by the NAFTA Environmental Side Accord. ${ }^{348}$

The Side Accord was created in an effort to achieve sustainable development. ${ }^{349}$ Although the agreement is an important recognition of the interrelated nature of trade and the environment, it does not create any new environmental laws. ${ }^{350}$ It allows for enforcement "against a NAFTA membernation only if it shows a 'persistent pattern' of failure to enforce its own environmental laws." 351 Several agencies have formed in response to NAFTA to facilitate dialogues on issues including environmental and water concerns. ${ }^{352}$

Although this addition to NAFTA was originally considered a success by environmentalists, further review has shown that other provisions of NAFTA may undermine potential environmental protection. ${ }^{353}$ Articles that allow

340. Id.; Dworsky \& Utton, supra note 134, at 448.

341. Mumme, supra note 17, at 355.

342. Dworsky \& Utton, supra note 134, at 448.

343. See id.

344. See Paulette L. Stenzel, The U.S. and Mexico Sin Fronteras-Without Borders: Sustainable Development from a Local Perspective, 27 WM. \& MARY ENVTL. L. \& POL'Y REV. 441, 443 (2002).

345. See id. In Piedras Negras, for example, a maquiladora for pants requires a disproportionate quantity of water to run the ten large washing machines. Coronado, supra note 272, $₫ 14$.

346. See Stenzel, supra note 344 , at 443.

347. Paule, supra note 7 , at 1131.

348. Id. at 1160 .

349. Stenzel, supra note 344 , at 443.

350. Id. at 464 .

351. Id.

352. Bennett \& Herzog, supra note 272, at 981 . These agencies include the Border XXI Framework, the Border Environment Cooperation Commission and the North American Development Bank, and the Commission for Environmental Cooperation. Id. at 981-84.

353. Stenzel, supra note 344 , at 464-65. 
companies to fight environmental enforcement mean that overall NAFTA is not doing enough for the protection of the environment, including water. ${ }^{354}$ Future agreements can learn from NAFTA's weaknesses and must do more to view consequences in Mexico as "our" problems as well. ${ }^{355}$

\section{Looking Above the Surface: Water Law Along the Border}

One of the complications for shared groundwater agreements along the U.S.-Mexico border is the varying laws in the four United States states and six Mexican states involved. ${ }^{356}$ In the United States, a federal statute regarding groundwater does not exist. ${ }^{357}$ "[W]ater rights, like most forms of property rights, arise under state law." ${ }^{358}$ Consequently, each state has different laws of ownership and use. ${ }^{359}$ In Mexico, water is governed on a national level. ${ }^{360}$ Local law must be considered when creating an international agreement because it is the operating procedure of the state involved. ${ }^{361}$

\section{State Groundwater Law}

\section{a. Texas}

Texas groundwater law is dictated by the "right of capture"362 and is closely tied to the notions of property ownership. ${ }^{363}$ Under this doctrine, the person who owns the land above the water has unlimited rights to the groundwater below. ${ }^{364}$ Texas courts have upheld this right even in situations when excess pumping by one landowner causes harm to a neighbor's land. ${ }^{365}$

The capture doctrine has been slightly modified by the state of Texas. ${ }^{366}$ Under common law, pumping that occurs with malice or wanton waste is prohibited. ${ }^{367}$ Additionally, in some situations, the aquifer can be defined as

354. Id. at 501.

355. See id.

356. Dworsky \& Utton, supra note 134, at 449 (listing the United States states of California, Arizona, Texas, and New Mexico and the Mexican states of Baja California, Sonora, Chihuahua, Coahuila, Nuevo Leon, and Tamaulipas).

357. Paule, supra note 7, at 1136.

358. Robert H. Abrams, Water Law, Trends, Policies and Practice 330 (1995).

359. See Mumme, supra note 17 , at 354.

360. Id. at 353-54.

361. See id.

362. TeX. Water Code AnN. $\S 36.002$ (Vernon 2000); Houston \& Tex. Cent. Ry. Co. v. East, 81 S.W. 279, 280 (Tex. 1904).

363. Kaiser \& Skillern, supra note 137, at 263.

364. Id.

365. Sipriano v. Great Spring Waters of Am., Inc., 1 S.W.3d 75 (Tex. 1998).

366. Opiela, supra note 136, at 101-05.

367. Id. at 101-04. 
an underground river, allowing it to be more regulated under a riparian rights doctrine than it would have been as groundwater. ${ }^{368}$

Perhaps the most significant and controversial modification of the rule of capture was the strengthening and expansion of groundwater conservation districts by 1997's Senate Bill 1 and Senate Bill 2 in 2001. ${ }^{369}$ These localized districts provide for groundwater management by preventing waste, performing research, and protecting the aquifer. ${ }^{370}$ Conservation districts can be formed by special legislature, petitions by property owners, or by the Texas Commission of Environmental Quality. ${ }^{371}$ The regulatory and oversight powers of these districts have been interpreted as an amendment to the absolute right to water. ${ }^{372}$

The right of capture has been widely criticized because it lacks any regulatory authority and does little to protect a limited resource. ${ }^{373}$ One of the major criticisms is the refusal of Texas courts to recognize the connection between surface water and groundwater. ${ }^{374}$ This allows upstream groundwater users to affect the downstream riparian users. ${ }^{375}$

\section{b. New Mexico}

In New Mexico, groundwater is considered property of the state and is allocated to users by prior appropriation. ${ }^{376}$ Prior appropriation is a permit system based on a person's previous and beneficial use of groundwater. ${ }^{377}$ "Typically, a groundwater appropriator is protected to a 'reasonable pumping level,' not necessarily the historical level . ..."378 The appropriation system uses criteria such as seniority of existing users and reasonableness to issue permits. $^{379}$

368. Id. at 104. Rivers, both surface and underground, are considered property of the state and use can be regulated. TEX. WATER CODE ANN. § 11.021 (Vernon 2000).

369. See Tex. Water Code ANN. § 36.005; Chris Lehman, Hung Out to Dry?: Groundwater Conservation Districts and the Continuing Battle to Save Texas's Most Precious Resource, 35 TeX. TECH L. REv. 101, 104-05 (2004) (describing the history and powers of groundwater conservation districts in Texas).

370. Bruce Lesikar et al., QUESTIONS ABOUT GROUNDWATER CONVERSATION Districts IN TEXAS 13 (2002).

371. Id. at 13-14.

372. See Lehman, supra note 369 , at 126-27.

373. See Opiela, supra note 136, at 87; Kaiser \& Skillern, supra note 137, at 251. See also David S. Brookshire, et al., Western Urban Water Demand, 42 NAT. RESOURCES. J. 873,873 (2002) (speaking out against the right of capture stating, "[t]he future viability of the arid Southwest will depend in large part on efficient use of increasingly scarce water resources").

374. See, e.g., Denis v. Kickapoo Lank Co., 771 S.W.2d 235 (Tex. App.-Austin 1989, writ denied).

375. See, e.g., id.

376. N.M. CONST. art. XVI, § 2.

377. Kaiser \& Skillern, supra note 137, at 268.

378. Id.

379. Caponera \& Alheritiere, supra note 18 , at 600. 
Unlike under a right of capture doctrine, water use is a privilege and not an absolute property right. ${ }^{380}$ Groundwater permits are managed and approved by the state engineer. ${ }^{381}$ Any sale of groundwater permits must also be approved by the state. ${ }^{382}$ New Mexico recognizes the link between surface and groundwater; therefore, permits are released after an examination of the possible effects on surface water users. ${ }^{383}$

Although New Mexico has a strict and integrated groundwater allocation system, the state faces future water problems. ${ }^{384}$ The growing population of the state creates a continuing need for new permits. ${ }^{385}$ Another difficulty is the radical difference in management philosophy held by New Mexico's neighbor, Texas. ${ }^{386}$ New Mexico's control over shared water is undermined when a neighboring state allows unlimited pumping. ${ }^{387}$

\section{c. Arizona}

Arizona is in the difficult position of having a highly arid climate and an agricultural base dependant on groundwater. ${ }^{388}$ Excessive pumping of wells has lowered water levels in some locations by as much as 400 feet. $^{389}$ The state uses the doctrine of reasonable use to control groundwater use. ${ }^{390}$ This allows a property owner to pump groundwater beneath his land only to the extent of beneficial and reasonable use. ${ }^{391}$

The Arizona Groundwater Management Act (GMA), passed in 1980, divided the state into regions based on type of use and water availability. ${ }^{392}$ Active Management Areas (AMAs), the highest regulated category, are restricted to previous groundwater amounts. ${ }^{393}$ Passage of the GMA created several groundwater doctrines in one state. ${ }^{394}$ Loose restrictions in the less regulated areas are often in conflict with the more stringent restrictions in the AMAs. ${ }^{395}$

\section{d. California}

380. Kaiser \& Skillern, supra note 137, at 291.

381. Id.

382. Barber, supra note 16, at 673.

383. Id. at 675.

384. Id.

385. Id.

386. Id.

387. Paule, supra note 7, at 1144.

388. Barber, supra note 16 , at 670-71.

389. Kaiser \& Skillern, supra note 137, at 274.

390. See Bristol v. Cheatham, 255 P.2d 173, 178 (Ariz. 1953).

391. See id.

392. ARIZ. Rev. Stat. ANN. $\S \S 45-401$ to $45-637$ (West 2001).

393. Kaiser \& Skillern, supra note 137, at 275-76.

394. Paule, supra note 7, at 1145.

395. Id. 
California uses a combination of prior appropriation and correlative rights to regulate groundwater use. ${ }^{396}$ Under correlative rights, property owners receive a "fair and just portion" of the groundwater and can be held liable if the withdrawal causes damage to neighboring land. ${ }^{397}$ In shortage areas, the courts determine "(1) the eligible well owners (pumpers), (2) how much water well owners can pump, and (3) the water master to monitor and ensure that the basin is managed in accordance with the court's decree." ${ }^{\prime 398}$ The mixture of adjudicated and legal doctrines makes water protection difficult, but the California legislature has refused to instate state-wide water regulations. ${ }^{399}$

\section{Mexican Groundwater Law}

Spanish law was similar to English common law stating that the owner of the overlying land was entitled to right of capture but added that groundwater underlying public lands constitutes public groundwater. ${ }^{400}$ After independence from Spain, Mexico retained the distinction between private and public waters. ${ }^{401}$

Groundwater policy was originally defined in the 1917 Constitution. ${ }^{402}$ Article 27 states that "[u]nderground waters may be brought to the surface by artificial works and utilized by the surface owner, but if the public interest so requires or use by others is affected, the Federal Executive may regulate its extraction and utilization, and even establish prohibited areas." ${ }^{, 403}$ Groundwater use is regulated by the government based on the order of priorities for the water source. ${ }^{404}$

Mexico has subsequently passed legislation to facilitate the governmental protection and control of groundwater use. ${ }^{405}$ In 1934, Mexico passed the National Water Law (Ley de Aguas Nacionales), which lays out the legal framework for all water usage and revised all water policy in Mexico. ${ }^{406}$ The Law of Conservation and Groundwater of 1956 (Le Ley de Conservacion del Suelo y Aguas) "established a system of restricted zones and a permit system

396. Barber, supra note 16 , at 669-70.

397. Kaiser \& Skillern, supra note 137, at 279 (quoting Hillside Water Co. v. City of Los Angeles, 76 P.2d 681, 686-87 (Cal. 1938).

398. Id.

399. Id. at 281.

400. Eckstein \& Eckstein, supra note 57, at 222-23.

401. Teclaff, supra note 134 , at 62.

402. See MEX. Const. art. 27 I 5 (amended 1983), available at http://www.ilstu.edu/class/hist263/ docs/1917const.html\#Article27 (last visited Sept. 19, 2003).

403. Id.

404. Barber, supra note 16 , at 663 .

405. Id.

406. Bennett \& Herzog, supra note 272, at 981. 
to regulate the development of groundwaters. ${ }^{\circ 407}$ More recently, Mexico created a National Water Commission (Comision Nacional de Agua) in part to regulate water use. ${ }^{408}$

It is certainly understandable that conflict might arise when Mexican national policy is forced to merge with four different state policies. ${ }^{409}$ The federalization of Mexico's groundwater and subsequent legislation reflect the country's views on the importance of water. ${ }^{410}$ International negotiations must consider the cultural attitude of a state towards a resource to create a successful agreement. ${ }^{411}$

\section{ANAlyzing Policy Options AND CREATING A RoAdMAP to AN AGREEMENT}

The most important step in the creation of an international groundwater agreement is realizing one is necessary. ${ }^{412}$ A more effective result is achieved by proactive planning rather than in the wake of an emergency. ${ }^{413}$ In the realm of water, a reactionary decision often limits the possibilities. ${ }^{414}$ The options for a water agreement along the United States-Mexico border are more numerous now than they will be once resources have been further depleted or contaminated. ${ }^{415}$ The time to act is now. ${ }^{416}$ Plans need to be developed between the two countries to understand common resources and how they can be used and protected in the future. ${ }^{417}$

Once it has been decided to create an accord, the parties must choose the basis of the policy. ${ }^{418}$ One of the exciting and daunting aspects of groundwater policy is that it is virtually uncharted territory. ${ }^{419}$ This being said, other sources of law can be used as models. ${ }^{420}$ These include oil and gas law, environmental

407. Stephen P. Mumme, The U.S. Conflict Over Transboundary Groundwaters: Some Institutional and Political Considerations, 12 CASE W. RES. J. INT'L L. 505, 518 (1980).

408. Bennett \& Herzog, supra note 272, at 981.

409. See Dworsky \& Utton, supra note 134, at 449.

410. Barber, supra note 16, at 664-65.

411. See id.

412. See Minute 242, supra note 334, 1 甲 5-6.

413. See e.g., Arias, supra note 80, at 199 (proposing conservation efforts before more environmental damage occurs).

414. See, e.g., id. (terminating groundwater pumping did not repair the irreversible damage to the river and surrounding vegetation).

415. See FREEZE \& CHERRY, supra note 19, at 329. Depending on local geology, the combination of long residence times for groundwater and recovery time needed after pumping, it is conceivable that a water source could be depleted faster than it can recharge. See id.

416. See Chavez, supra note 1, at 237-38, 250-51 (explaining that the current water situation in El Paso will not sustain the city into the future).

417. See Mumme, supra note 17, at 361.

418. See, e.g., Rodgers \& Utton, supra note 32, at 165-210; Hayton \& Utton, supra note 242, at 663 (providing examples of sample treaties and agreement options for governments).

419. Rodgers \& Utton, supra note 32, at 151.

420. See Ernst Willheim, Australia-Indonesia Sea-Bed Boundary Negotiations: Proposals for a Joint 
law, and state law. ${ }^{421}$ Although these can serve as a useful beginning, the differences and unique circumstances groundwater presents need to be recognized and included in the process. ${ }^{422}$

In addition to existing law, several factors should be considered in the drafting of any groundwater agreement. ${ }^{423}$ These criteria are the result of academic and international organizations, as well as trial and error from past accords. ${ }^{424}$ A critical examination of the options with local issues can help achieve a working arrangement specifically designed for a certain area. ${ }^{425}$

\section{A. International Shared Oil \& Gas Law}

Oil and gas resources often cross international boundaries creating the need for a use agreement. ${ }^{426}$ Many examples exist of accords established to develop the common resource in the interim of the boundary dispute. ${ }^{427}$ Although groundwater can be distinguished from petroleum by its lifesustaining function, many of the issues faced in international resource law are applicable to water policy. ${ }^{428}$

Similar to oil and gas, access to water is linked to property rights. ${ }^{429}$ A country has a right to use what lies beneath its territory. ${ }^{430}$ But even for hydrocarbon deposits, international law governs that one state must not take unilateral action if it "risks depriving other states of the gains they might realize." 431 One state must notify the other state of any intent to harvest a shared resource. ${ }^{432}$ These theories also apply to water because one country cannot deprive another of sustainability. ${ }^{433}$

Development is usually limited to the extent that it harms the sharing party. ${ }^{434}$ Harm is defined as one country taking more than its share. ${ }^{435}$ Most

Development Zone in the "Timor Gap," 29 NAT. RESOURCES J. 821 (1989).

421. See, e.g., id.; Paule, supra note 7, at 1156-58; Teclaff \& Teclaff, supra note 32, at 642-47 (listing water treaties based on and including environmental provisions).

422. See BENVENISTI, supra note 42, at 104.

423. See Helsinki Rules, supra note 202.

424. See id.; Watercourse Convention, supra note 198, at art. 6(1).

425. See Helsinki Rules, supra note 202.

426. See, e.g., Willheim, supra note 420 , at 821.

427. See id. at 832-34 (listing joint development agreements between Thailand and Malaysia, the Republic of Korea and Japan, and Saudi Arabia and Kuwait).

428. BENVENISTI, supra note 42, at 104.

429. REX. J. ZEDALIS, INTERNATIONAL ENERGY LAW 72 (2000).

430. Id.

431. David M. Ong, Joint Development of Common Offshore Oil and Gas Deposits: “Mere” State Practice or Customary International Law?, 93 AM. J. INT’L L. 771, 798 (1999).

432. Id. at 802 .

433. See Joseph W. Dellapenna, Treaties as Instruments for Managing Internationally-Shared Water Resources: Restricted Sovereignty vs. Community of Property, 26 CASE W. RES. J. INT'L L. 27, 30-31 (1994).

434. ZEDALIS, supra note 429 , at 72 .

435. Id. at 73 . 
joint development arrangements create an authority to facilitate the agreement. ${ }^{436}$ Many of these agreements also present useful alternatives for approaching differing national laws and customs, profit sharing, and dispute resolution to realize a common goal. ${ }^{437}$

A distinction needs to be made between joint development and joint use. ${ }^{438}$ Development is used in the petroleum context because the resource is accessed until ultimately emptied. ${ }^{439}$ In contrast, negotiations regarding water are usually initiated to determine its use over time. ${ }^{440}$ Unlike oil and gas reserves, most aquifers are renewable and are difficult to delineate, making the terms of a use agreement different. ${ }^{441}$ Although differences between water and other resources bar the direct application of oil and gas agreements to water, their similar roots in property law create a useful starting point for policy. ${ }^{442}$

\section{B. International Environmental Law}

International environmental law is another possible source of future groundwater policy. ${ }^{443}$ This twentieth century emerging doctrine was created in response to environmental degradation. ${ }^{444}$ Issues such as political sovereignty and culture create a beneficial tool for international treaties in other arenas. ${ }^{445}$ Additionally, the United Nations recommendation to apply other international law in the absence of a water agreement makes familiarity valuable. ${ }^{446}$

Fear of groundwater pollution motivates accord creation to protect transboundary water sources. ${ }^{447}$ Past treaties focus on maintaining water quality of surface water and protecting flow quantity. ${ }^{448}$ Many interconnected

436. Willheim, supra note 420 , at $832-33$.

437. Id. at 836-39.

438. Compare id. at 831-39 (showing an example of joint development), with Wohlwend, supra note 61, at 1 (showing an example of joint use).

439. See, e.g., Willheim, supra note 420 , at 821.

440. See, e.g., Wohlwend, supra note 61 , at 1 .

441. BENVENISTI, supra note 42, at 27. Some fossil aquifers are not renewable creating a larger problem when unmonitored mining occurs. See id. Although most aquifers are considered renewable, the residence time required to recharge many aquifers is so high that a city would be forced to find an alternate water source. See ToDD, supra note 21, at 24-25.

442. See Willheim, supra note 420, at 831-39.

443. See Teclaff \& Teclaff, supra note 32, at 629; AlEXANDre Charles Kiss, SURVEY OF CuRRENT DEVELOPMENTS IN INTERNATIONAL ENVIRONMENTAL LAW 29-40 (IUCN Environmental Policy and Law Paper, No. 10, 1976).

444. Lori F. DAMrosch ET AL., INTERnATIONAL LAW: CASES AND MATERIALS 1509 (4th ed. 2001) (1980).

445. See Albert E. Utton, International Water Quality Law, in INTERNATIONAL ENVIRONMENTAL LAW 157 (Ludwik A. Teclaff \& Albert E. Utton eds., 1974).

446. Caponera \& Alheritiere, supra note 18, at 613-14 (citing Report of the United Nations Water Conference, Mar del Plata Conference, at 51, U.N. Doc. E/Conf.70/CBP/1 (1977)).

447. Teclaff \& Teclaff, supra note 32 , at 636-39.

448. Id. at $636-37$ 
aquifers have been indirectly protected by these regulations. ${ }^{449}$ More recent treaties contain specific provisions to protect groundwater. ${ }^{450}$ Once the interrelated nature of surface and groundwater was recognized, the focus of treaties began to shift. ${ }^{451}$

Current agreements often regulate surface water quality to the detriment of groundwater. ${ }^{452}$ Surface water quality regulations often increase the probability of waste being placed on the ground, which can percolate down and contaminate groundwater sources. ${ }^{453}$ A few modern agreements were specifically created to protect groundwater. ${ }^{454}$ These can be helpful to wateruse accords by setting a framework and opening a dialog between two states regarding shared resources. ${ }^{455}$ Future water allocation policy needs to mention groundwater specifically and encompass an entire aquifer system to be effective. ${ }^{456}$

As seen in oil and gas joint development agreements, environmental agreements often create commissions for management. ${ }^{457}$ Duties of the commission vary depending on the terms of the treaty. ${ }^{458}$ Policy characteristics such as the concepts of international responsibility, cooperation, and enforcement are also useful to water policy authors. ${ }^{459}$ For example, international law principles, such as the idea that one nation should not harm another, have been applied in the environmental context and should be used in water policy. ${ }^{460}$

The key difference between water and environmental law is water law's roots in property law. ${ }^{461}$ A direct application of environmental law would require a change of perspective. ${ }^{462}$ Water needs to be viewed as more than an economic resource. ${ }^{463}$ This is an appropriate change in thinking for a number of reasons. ${ }^{464}$ First, water's life-sustaining function sets it apart from a mere

449. Id. at 637.

450. Id. at 638 .

451. Id. at 639 .

452. Id. at 641 .

453. Id.

454. Id. at 642-47.

455. See id.

456. See Utton, supra note 445 , at $154-55$.

457. Teclaff \& Teclaff, supra note 32, at 647; see Utton, supra note 445, at 174-77 (explaining that the use of commissions to plan and maintain the drainage basin is the best way to deal with state sovereignty issues).

458. Teclaff \& Teclaff, supra note 32, at 647-51.

459. KIss, supra note 443, at 29, 41-55; Lynton K. Caldwell, Concepts in Development of International Environmental Policies, in INTERNATIONAL ENVIRONMENTAL LAW 12, $12-13$ (Ludwik A. Teclaff \& Albert E. Utton eds., 1974) ("[N]ations should cooperate to serve the mutual interests of their respective peoples.").

460. Caldwell, supra note 459, at 12.

461. Kaiser \& Skillern, supra note 137, at 251.

462. See id.

463. See Caldwell, supra note 459 , at 16 .

464. See BenVEnISTI, supra note 42, at 104. 
economic commodity. ${ }^{465}$ Second, although water is often treated as a property right, water does not fit well into a property construct. ${ }^{466}$

The following factors are required for the assignment of property rights to a watercourse: First, the resource must be able to be divided both physically and economically. Second, distribution must be accepted by all riparians and protected from non-owners. Finally, transaction costs of water rights should be low to make trade profitable. ${ }^{467}$ The physical characteristics of water make it impossible for it to adhere to these guidelines. ${ }^{468}$ Redefining water as a resource would make it easier to legally address. ${ }^{469}$

\section{State Law}

Existing surface and groundwater law along the United States-Mexico border may be a natural choice for international agreements, but many problems can arise. ${ }^{470}$ One of the problems with applying state law to an international agreement is deciding whose law prevails when two or three different legal structures are involved. ${ }^{471}$ This is a critical decision because some groundwater law is more stringent than others and can have serious effects on the outcome. ${ }^{472}$

Lack of existing regulation along the Mexico border means water belongs to whoever can access it first. ${ }^{473}$ Choosing Texas's right of capture for an agreement would not change the current situation along the border. ${ }^{474}$ This system of allocation has proven ineffectual based on current water shortages. ${ }^{475}$ Therefore, direct application of Texas law should be avoided. ${ }^{476}$

Other state law options such as prior appropriation would also be difficult to apply. ${ }^{477}$ The permitting system used by prior appropriation states is in large part based on past water use. ${ }^{478}$ Although permitting is a viable solution, insufficient records by any state bar the ability to assign permits based on prior usage. ${ }^{479}$ Governmental ownership systems such as Mexico's are also not

465. Id.

466. See Benvenisti, supra note 6, at 395-96.

467. Id.

468. See id. at 396.

469. See id. at 395-98.

470. See Paule, supra note 7, at 1136-50.

471. See id.

472. See Kaiser \& Skillern, supra note 137, at 274-81, 290-92.

473. See Chavez, supra note 1, at 250-51.

474. See Opiela, supra note 136, at 88-89; Chavez, supra note 1, at 250-51.

475. See Chavez, supra note 1, at 250-51.

476. See Opiela, supra note 136, at 88-89.

477. See Kaiser \& Skillern, supra note 137, at 268.

478. See id.

479. See id. 
applicable across borders. ${ }^{480}$ Water flowing beneath two states cannot be owned and utilized by only one. ${ }^{481}$

State practices such as correlative rights and reasonable use do have application value outside their state of origin. ${ }^{482}$ Under both of these doctrines, a party's water allocation depends on the amount used for a beneficial purpose. ${ }^{483}$ The reasonable use doctrine was created when circumstances forced the modification of the rule of capture. ${ }^{484}$ Conflicts between users are resolved by "comparing pumping rates and uses against reasonableness criteria." ${ }^{485}$ In order to prevent waste, reasonableness is determined by several factors, including well location, water quantity, and water use. ${ }^{486}$ Under correlative rights, pumping is only limited if a shortage exists. ${ }^{487}$

Although a direct application of one state's law over another's may not be feasible, the ideas of reasonable use and alternatives to an absolute right to water should be incorporated into any international agreement. ${ }^{488}$ Prior use can be considered, but an absolute right within a state cannot be guaranteed to carry across a border. ${ }^{489}$ Consideration of a state's current laws is also critical for a cooperative effort. ${ }^{490}$

\section{Factors}

The purpose of an international agreement should be to successfully use and protect a shared resource in a manner that is fair and sustainable. ${ }^{491}$ To accomplish this, certain factors should be considered. ${ }^{492}$ These range from factual information such as scientific scenarios and economic impacts to less tangible issues including negotiation principles and reasonableness. ${ }^{493}$ Lists of factors to obtain reasonable and equitable use were created by the Helsinki

480. See Mex. Const. art. 27 9 5 (amended 1983), available at http://www.ilstu.edu/class/hist263/ docs/1917const.html\#Article27 (last visited Sept. 19, 2003).

481. See Paule, supra note 7, at 1130.

482. See Kaiser \& Skillern, supra note 137, at 264-67.

483. Id.

484. Id. at 264 .

485. Id. at 265 .

486. Id.

487. Id. at 267.

488. See id. at 264-67.

489. See id. at 267.

490. See Bennett \& Herzog, supra note 272, at 978-79.

491. See Hayton \& Utton, supra note 242, at 682 ("The Parties recognize their common interest and responsibility in ensuring the reasonable and equitable development and management of groundwaters in the border region for the well being of their Peoples.") (alteration in original).

492. See Helsinki Rules, supra note 202.

493. See id.; Watercourse Convention, supra note 198, at art. 6(1). 
Rules and the ILC. ${ }^{494}$ These have been expanded and modified by scholars and proposed agreements. ${ }^{495}$ Although some of the concepts are generally applicable, others have particular significance along the United States-Mexico border. ${ }^{496}$

\section{Approaching the Agreement}

One of the most important factors that can determine the success of an agreement cannot be found in the words. ${ }^{497}$ A large part of water issues are political; therefore, the nontangible goals and attitudes of the parties and the manner they approach the negotiations are vital parts of the process. ${ }^{498}$ Because of the complexities of international law and the complications geology can add to the situation, parties should use an interdisciplinary approach to any negotiation. ${ }^{499}$ International law needs to be flexible enough to deal with different situations surrounding shared groundwater but specific enough to demand the cooperation necessary. ${ }^{500}$

Water is needed by everyone; consequently, governments need to focus on sustainable development of the affected society as a whole. ${ }^{501}$ "States ... can no longer define their self-interests solely in terms of political boundaries." 502 Part of this process is ceasing to view water as an economic resource. ${ }^{503}$ Considering water as only an economic commodity minimizes its necessity to users. ${ }^{504}$ Unlike oil and gas, the need for shared water extends across the border. ${ }^{505}$ Future laws should focus on use and control of water, not ownership. ${ }^{506}$

In the alternative, if water is considered a commodity, the need to negotiate a use agreement remains. ${ }^{507}$ The U.S. Supreme Court's recent decision that water is an article of commerce has applicability in an

494. See supra text accompanying notes 210, 223; Helsinki Rules, supra note 202; Watercourse Convention, supra note 199, at art. 6(1).

495. See, e.g., Hayton \& Utton, supra note 242, at 664.

496. See discussion infra Part IV.D.1-5.

497. See Utton, supra note 28, at 112-14.

498. See Bennett \& Herzog, supra note 272, at 987-88. "Indeed, states' control over national natural resources has been a major factor for both unsustainability and human maltreatment. As demands for these resources increased, so did the governments' inclination to use them as a domestic political tool." BENVENISTI, supra note 42, at 14-15.

499. See Hayton \& Utton, supra note 242, at 664.

500. Caponera \& Alheritiere, supra note 18, at 591.

501. See Stenzel, supra note 344, at 441.

502. McCaffrey, supra note 8, at 139.

503. See BENVENISTI, supra note 42, at 104.

504. See id.

505. See McCaffrey, supra note 8, at 139 .

506. Utton, supra note 28, at 113.

507. See Sporhase v. Nebraska ex rel. Douglas, 458 U.S. 941, 947-54 (1982). 
international context. ${ }^{508}$ Although the U.S. Constitution cannot be legally enforced outside the country, the philosophy behind the decision can be incorporated into negotiations. ${ }^{509}$ According to the Commerce Clause, geographic prohibitions of an article affecting commerce within the United States are generally unconstitutional. ${ }^{510}$ Members of neighboring states have rights to those products and their flow across borders should not be inhibited. ${ }^{511}$

The border's purpose as a barrier between the United States and Mexico has become increasingly ineffectual as a joint economy evolves. ${ }^{512}$ The NAFTA opened borders for products as well as a work force, moving away from a state-centric approach towards a market economy. ${ }^{513}$ If water is considered a product of commerce, it would follow that NAFTA's freedom of motion principles would extend to it. ${ }^{514}$ Whether water is considered an economic resource or a basic human right, the collective-action problem requires cooperation among parties for allocation. ${ }^{515}$

Unfortunately, cooperation in past agreements has been used to widen the power gap, not maximize the resource. ${ }^{516}$ Because water is needed for survival, agreements should attempt to satisfy all participants' long-term needs. ${ }^{517}$ "Cooperation in the utilization of water resources should be recognized as a long-term effort based on collective action for an indefinite time period, rather than as a discrete transaction ...." ${ }^{518}$ Although cooperation is not required by international law, practice has shown its benefits. ${ }^{519}$

A useful starting point for cooperation is the international law principle to avoid causing harm to another state. ${ }^{520}$ In the context of water, this could occur by exploitation or pollution of a shared resource. ${ }^{521}$ The principle of "avoiding harm" has been echoed by many international treaties and is clearly enunciated in many UN resolutions, ILA rules, and ILC recommendations. ${ }^{522}$ This goal can be satisfied by open communication between the nations and notification of withdrawals. ${ }^{523}$ Notice of water removal by one state allows the

508. See id. at $984-60$

509. See id.

510. U.S. Const. art. I, § 8, cl. 3.

511. See id.

512. See Stenzel, supra note 344, at 443.

513. See id. at 451-52.

514. See Sporhase, 458 U.S. at 941.

515. Benvenisti, supra note 6, at 388-89.

516. BENVENISTI, supra note 42 , at $43-44$.

517. See Benvenisti, supra note 6, at 399.

518. Id. at 399-400.

519. Id. at 412-13.

520. See Barberis, supra note 26, at 169.

521. See id. at 169-70.

522. See id. at 170-71.

523. See id. at 177-79. 
other state to object if harm will be caused, causing the water to be used equitably. ${ }^{524}$

\section{Equitable Utilization}

Equitable utilization is based on two states individually developing a shared resource on their respective side of the border without causing appreciable harm to the other. ${ }^{525}$ At present, water allocations along the United States border are far from equitable. ${ }^{526}$ Many Mexican colonias can barely meet their water needs, while United States residents have an abundant supply. ${ }^{527}$ To achieve long-term sustainability, efforts must be made to create a better balance between use and need. ${ }^{528}$

The reasonable and equitable use model is evidenced in most international resource treaties and is the cornerstone of most groundwater law recommendations. ${ }^{529}$ Equitable utilization is the sole purpose of the Helsinki Rules' factors. ${ }^{530}$ The flexibility intrinsic in this doctrine contributes to its effectiveness. ${ }^{531}$ Extremes such as territorial sovereignty and absolute liability yield to a standard of reasonableness. ${ }^{532}$ Although some critics believe the undefined concept is too vague, with proper institutional enforcement, the balance between structure and elasticity is necessary for a working agreement. ${ }^{533}$

Equitable does not necessarily mean equal. ${ }^{534}$ One solution would be to allow a state access only to the quantity of water directly beneath it, but this may not be the best solution depending on other surrounding circumstances. ${ }^{535}$ Consideration of many factors seeks to create a balance between the states. ${ }^{536}$ The total benefits and detriments to a state are weighed to determine allocation quantities. ${ }^{537}$ Utilization is based on the individual needs of an area. ${ }^{538}$ This

524. See id.

525. See id. at 175.

526. Coronado, supra note $271, \uparrow 13$.

527. Id.

528. See id.

529. See Helsinki Rules, supra note 202, at art. IV; Watercourse Convention, supra note 199, at art. $6(1)$.

530. See Helsinki Rules, supra note 202, at art. IV ("Each basin State is entitled, within its territory, to a reasonable and equitable share in the beneficial uses of the waters of an international drainage basin.").

531. See Utton, supra note 445 , at 168-69.

532.

532. Id.

533. Id. at 170-71.

534. See Helsinki Rules, supra note 202, at art. IV.

535. See Barberis, supra note 26, at 177-78.

536. See Helsinki Rules, supra note 202, at art. IV.

537. See Barberis, supra note 25, at 177.

538. WATERS AND WATER RIGHTS, supra note 413, at 37. 
flexible and individual treatment of basins creates a framework to build a workable agreement. ${ }^{539}$

\section{Surface Water/Groundwater Relationship}

A groundwater agreement would be incomplete without considering the relationship between surface water and groundwater. ${ }^{540}$ Consideration of the entire drainage basin was the landmark recommendation of the Helsinki Rules. $^{541}$ Although initially resisted by the ILC, the basin concept was ultimately incorporated into its recommendations as well, further confirming its importance..$^{542}$

Evaluation of surface water in conjunction with groundwater is necessary because of geologic principles. ${ }^{543}$ Water in any form is part of an interrelated cycle, and the quantity of water on the planet is unchanging. ${ }^{544}$ In addition to the hydrologic cycle relationship, water bodies are often directly related to one another hydrologically. ${ }^{545}$ Many rivers obtain their base flow from aquifers, and the reverse can also occur. ${ }^{546}$ An agreement that focuses on the allocation of only one water type might inadvertently damage an adjacent water body. ${ }^{547}$

Consideration of the entire basin would also protect areas where a water source is located on one side of the border but the primary source for recharge is found on the other ${ }^{548}$ In this scenario, the latter state could cause appreciable harm to the former's water source without pumping a drop. ${ }^{549}$ The expanse of geologic possibilities requires politicians to consider the science of an area to create the most functional agreement for a particular region. ${ }^{550}$

\section{Regional Agreements}

The United States and Mexico could develop an agreement that applies to all shared groundwater along the border, but the scope of an agreement can determine its effectiveness. ${ }^{551}$ Geologic differences and varying needs could make a border-wide agreement difficult and ultimately unsuccessful. ${ }^{552}$ Global

539. See Utton, supra note 445 , at 168-69.

540. See McCaffrey, supra note 8, at 139-40; Utton, supra note 28, at 112-13.

541. See Helsinki Rules, supra note 202.

542. See Thirty-Second Session, supra note 219, Supp. No. 10, at 247.

543. See Eckstein \& Eckstein, supra note 57, at 235-48.

544. TODD, supra note 21, at 42; FREEZE \& CHERRY, supra note 19, at 3-4.

545. See id. at 222-27.

546. See id. at 225-27.

547. See Eckstein \& Eckstein, supra note 57, at 222-27.

548. See id.

549. See id.

550. See id. at 235-48.

551. Hayton, supra note 191, at 71.

552. See supra Part II.A; Utton, supra note 445, at 169-70 ("Each drainage basin is a unique entity 
agreements for surface water are somewhat more functional because of the linear structure of a river with clear upstream and downstream users. ${ }^{553}$ Contrarily, aquifers are generally localized despite possible hydrologic connections to surface water. ${ }^{554}$ Aquifers affect a restricted community with individual concerns. ${ }^{55}$ These issues must be considered in an agreement, which is difficult to accomplish in a large scale accord. ${ }^{556}$

The Franco-Swiss Genevese Aquifer agreement exemplifies the advantages of a regional approach. ${ }^{557}$ Two governments created a use policy and an enforcement commission that could be regulated on a local level to solve a common problem. ${ }^{558}$ The agreement focuses on equitable utilization and resists the notion of territorial sovereignty to fulfill the needs of the area for more than twenty-five years. ${ }^{559}$ The accord's success has been partially attributed to its tailor-made, area-specific details. ${ }^{560}$

The value of a tailor-made agreement founded on regional needs can be seen by comparing the Upper San Pedro River Basin and the El Paso/Ciudad Juarez case. ${ }^{561}$ Both of these areas have concerns regarding shared aquifers that cross the United States-Mexico border. ${ }^{562}$ Although their concern is facially similar, the issues challenging each region are considerably different, creating the need for diverse solutions. ${ }^{563}$

The Upper San Pedro River Basin has a sufficient water supply, but environmental concerns regarding excessive pumping lowering the water table have arisen. ${ }^{564}$ A lower water table has significant ecologic effects on migratory birds ${ }^{565}$ Part of the problem is the geologic relationship between the San Pedro River and two interconnected aquifers. ${ }^{566}$ Public hearings between the two countries led to an agreement regarding the value of the river basin and proposed site-specific solutions to prevent further harm. ${ }^{567}$ An effective agreement needs to consider geology and the specific regional problems. ${ }^{568}$

(...").

553. See, e.g., Treaty Relating to the Utilization of Waters of the Colorado and Tijuana Rivers and of the Rio Grande, Nov. 14, 1944, and Supplementary Protocol, U.S.-Mex., art. 2, 59 Stat. 1219.

554. See FREEZE \& CHERRY, supra note 19, at 48.

555. See, e.g., Arias, supra note 80, at 199.

556. See Coronado, supra note $271, \uparrow 23$ ("Sister cities could elaborate an equitable plan to share water resources, always keeping in mind the needs of other communities and water users in the region.”).

557. See Wohlwend, supra note 61 , at 1 .

558. Id. at $2-3$.

559. See id. at 10-11.

560. See id. at 6 .

561. See Arias, supra note 80, at 199; Chavez, supra note 1, at 237.

562. Arias, supra note 80, at 203-05; Chavez, supra note 1, at 239-40.

563. See Arias, supra note 80, at 212-17; Chavez, supra note 1, at 237.

564. Arias, supra note 80, at 199.

565. Id.

566. Id. at 203-05.

567. Id. at 212-17.

568. See id. at 213-17. 
In contrast, water issues in El Paso and Ciudad Juarez exclusively spring from insufficient water quantity aggravated by rapidly increasing population on both sides of the border. ${ }^{569}$ The shared Hueco Bolson aquifer is more hydrologically isolated than the San Pedro Basin aquifers. ${ }^{570}$ Although some interrelatedness has been found between the aquifer and the Rio Grande River, current concerns have not resulted from this relationship but rather from overexploitation of the aquifer. ${ }^{571}$ Negotiations between the two cities focused on water allocation and alternative water sources. ${ }^{572}$

The substantial differences between these geographically proximate aquifers reinforce the notion that regional agreements are the most effective approach to international water agreements. ${ }^{573}$ Regional agreements are also "conducive to recognition of similar needs and methods in the relations between and among States." 574

A regional approach can have weaknesses. ${ }^{575}$ Perhaps the largest of these is enforcement. ${ }^{576}$ Is there a method to enforce an agreement between two municipalities? Processes must be put into place to preserve the agreement's integrity and sustainability, or its objective can be easily undermined. ${ }^{577}$

\section{Enforcement}

The United States Constitution provides little guidance regarding treaty formation and enforcement. ${ }^{578}$ The President "shall have the Power, by and with the Advice and Consent of the Senate, to make Treaties, provided two thirds of the Senators present concur." ${ }^{\text {,579 }}$ The Cases and Controversies Clause extends judicial power to treaties, but although the Supremacy Clause further limits treaties, it does not define them. ${ }^{580}$ The Compacts Clause prohibits states from creating treaties with other nations but does allow compacts or agreements to be made with the consent of Congress. ${ }^{581}$

569. Chavez, supra note 1 , at 237

570. See J.C. Day, International Aquifer Management: The Hueco Bolson on the Rio Grande River, 18 NAT. RESOURCES J. 163, 164-70 (1978).

571. Chavez, supra note 1, at 237; see Walton \& Ohlmacher, supra note 111, at 3.

572. See Chavez, supra note 1, at 246-50.

573. Compare Arias, supra note 80, at 199 (describing the regional and geologic characteristics of the San Pedro Aquifer), with Chavez, supra note 1, at 237 (describing the regional and geologic characteristics of the Hueco Bolson Aquifer).

574. Hayton, supra note 191, at 92.

575. See DAMrosch ET AL., supra note 444, at 22-23.

576. See id.

577. See id.

578. See U.S. CONST.

579. Id. at art. II, $\S 2$.

580. Id. at art. III, § 2, art. VI, cl. 2 ("This Constitution, and the Laws of the United States which shall be made in Pursuance thereof; and all Treaties made, or which shall be made, under the Authority of the United States, shall be the supreme Law of the Land.").

581. Id. art. I, $\S 10$, cl. 3 . 
At the international level, many questions arise regarding enforcement of treaties. ${ }^{582}$ One of the most useful and common types of enforcement is voluntary compliance. ${ }^{583}$ Sanctions, both forcible and nonforcible, detailed within the treaty and the possible remedies within national courts also encourage conformity. ${ }^{584}$ The creation of a local regulatory commission is a popular and effective tool for enforcement, especially in regional agreements. ${ }^{585}$

Regional organizations encourage participation for an agreement on a local level. ${ }^{586}$ Joint creation eases the transition from state sovereignty to cooperative interactions. ${ }^{587}$ Commissions can be locally created with areaspecific duties or federally created and responsible for a larger region. ${ }^{588}$ Agencies can serve as technical advisors for local hydrogeology, monitor groundwater withdrawals, and perform dispute resolution. ${ }^{589}$ The national power creating the commission determines the extent of its authority. ${ }^{590}$

Along the United States-Mexico border, the IBWC is a natural choice to regulate future agreements. ${ }^{591}$ The IBWC's long history of enforcement and broad range of powers could facilitate both nationwide as well as federally approved regional agreements. ${ }^{52}$ The unusual autonomy of the IBWC ameliorates the Constitutional prohibition on local international agreements. ${ }^{593}$ Agency approval of proposed arrangements would probably not preclude the need for congressional approval, but it could hasten the process. ${ }^{594}$

An additional enforcement advantage along the Mexico border is the consejos de cuencas. ${ }^{595}$ These binational watershed councils are familiar with regional water issues and local politics. ${ }^{596}$ Their personal connections with the people affected would assist in cooperative practice. ${ }^{597}$ The consejos de cuencas together with the IBWC create a powerful framework for the

582. DAMROSCH ET AL., supra note 444, at 22.

583. Id. at 23 .

584. Id.

585. See Caponera, supra note 218, at 17-25 (listing international river commissions created worldwide).

586. See Wohlwend, supra note 61, at 6. One of the remarkable aspects of the Franco-Swiss Agreement is that it was created and is regulated on a regional level. $I d$. at 3.

587. See Utton, supra note 445 , at $174-75$.

588. Compare Wohlwend, supra note 61 , at 6 (providing an example of regional organization in the case of the Franco-Swiss agreement), with Mumme \& Moore, supra note 315, at 661-63 (describing the IBWC, a federal regulatory agency).

589. See Hamner \& Wolf, supra note 38 , at 166.

590. See Mumme \& Moore, supra note 314, at 663, 666.

591. See id. at 661-63.

592. See Joachim Blatter \& Helen Ingram, States, Markets and Beyond: Governance of Transboundary Water Resources, 40 NAT. RESOURCES J. 439, 444-45 (2000).

593. See Mumme \& Moore, supra note 314 , at 667, 669.

594. See id.

595. See discussion supra Part III.B; Brown \& Mumme, supra note 321, at 895.

596. See Brown \& Mumme, supra note 321, at 895.

597. See id. 
enforcement of groundwater agreements on the United States-Mexico border. ${ }^{598}$ Threats of severe water shortages, seventeen shared transboundary aquifers, and the necessity of water, coupled with existing institutional support, overwhelm any grounds to delay action. ${ }^{599}$

\section{CONCLUSION}

In many regions of the world, water is running out. ${ }^{600}$ As communities search for alternative drinking water sources, increasing numbers are turning to groundwater to meet their growing needs. ${ }^{601}$ As dependence on groundwater escalates, so do the opportunities for conflict. ${ }^{602}$ This is especially true in situations where more than one state can claim ownership of the resource. ${ }^{603}$

The United States and Mexico share several aquifers underneath their common border. ${ }^{604}$ Although treaties are in place between the two countries to allocate surface water, no policy exists to distribute shared subsurface water resources. ${ }^{605}$ To achieve long term sustainability, agreements must be promptly created to equitably allocate water among parties. ${ }^{606}$

Groundwater agreements can derive successful methods from other types of law and scholarly disciplines, but its unique characteristics require agreements be customized for regional issues including geology, custom, and needs. ${ }^{607}$ Other factors, including cooperation and the relationship between surface water and groundwater, need to be included in all future accords. ${ }^{608}$

The invisibility of aquifers makes its disappearance difficult to imagine, but the threat is real. ${ }^{609}$ " "The challenge ahead is for us to transcend the selfinterests of our respective nation-states so as to embrace a broader self-interest - the survival of the human species in a threatened world." "610

by Amy Hardberger

598. See id. at 910-11.

599. Mumme, supra note 17, at 363-77; Chavez, supra note 1, at 237-39; Mumme \& Moore, supra note 314 , at 661 .

600. See, e.g., Coronado, supra note 271 , 9 甲 1-2.

601. See Sampat, supra note 27, at 10-13.

602. See id.

603. See, e.g., Mumme, supra note 17, at 363-77.

604. See id.

605. See Chavez, supra note 1, at 237-39; Szekely, supra note 323, at 397.

606. See, e.g., Chavez, supra note 1, at 237.

607. See discussion supra Part IV.A-C.

608. See Benvenisti, supra note 6, at 388-89; Utton, supra note 445, at 168-69.

609. Rodgers \& Utton, supra note 32, at 152.

610. World Commission on Environment and Development: Public Hearing, Ottawa, Canada (1986) (statement of T. McMillan, Minister of Environment, Government of Canada), reprinted in WCED, Our Common Future 263 (1987). 